\title{
The addition of halogens and interhalogens on palladacyclopentadienyl complexes bearing quinolyl-thioether as spectator ligands. A kinetic and computational study
}

\author{
L. Canovese ${ }^{\mathrm{a}, *}$, F. Visentin ${ }^{\mathrm{a}}$, T. Scattolin ${ }^{\mathrm{a}}$, C. Santo ${ }^{\mathrm{a}}$, V. Bertolasi ${ }^{\mathrm{b}}$ \\ a Dipartimento di Scienze Molecolari e Nanosistemi, Università Ca' Foscari, Venice, Italy \\ ${ }^{\mathrm{b}}$ Dipartimento di Chimica e Centro di Strutturistica Diffrattometrica, Università di Ferrara, Ferrara, Italy
}

\section{A R T I C L E I N F O}

\section{Article history:}

Received 17 February 2016

Accepted 6 April 2016

Available online 13 April 2016

\section{Keywords:}

Thioquinoline-palladiumcyclopentadienyl

complexes

Kinetic study

Halogens

Interhalogens

Dienes extrusion

\begin{abstract}
A B S T R A C T
We have studied the oxidative addition of halogens $\left(\mathrm{I}_{2}\right.$ and $\left.\mathrm{Br}_{2}\right)$ and interhalogens (ICl and $\mathrm{IBr}$ ) on complexes of the type $\left[\mathrm{Pd}(\right.$ thioquinoline $\left.) \mathrm{C}_{4}(\mathrm{COOMe})_{4}\right]$, (thioquinoline $=8$ - $($ methylthio $)$ quinoline, 8-(t-butylthioquinoline, 2-methyl-8-(methylthio)quinoline, 2-methyl-8-( $t$-butylthio)quinoline).

The expected palladium(thioquinoline)- $\sigma$-butadienyl derivatives have been obtained by the stoichiometric addition of $\mathrm{I}_{2}$ and $\mathrm{Br}_{2}$ to a solution of the starting palladacyclopentadienyl complexes. The bromine in excess induces the extrusion of the di-bromo-(E, E)- $\sigma$-butadiene and the formation of the thioquinoline palladium(II) di-bromide species. The kinetics and mechanism of these reactions have been determined.

Except for one case which was analyzed in detail by a computational study, the oxidative addition of the interhalogens $\mathrm{ICl}$ and $\mathrm{IBr}$ yields the species that is less predictable from the thermodynamic point of view. In general the computational approach justifies the reaction progress and allows an interpretative clue suggesting a kinetically governed path to the reaction products.

Finally, the solid state structures of two reaction products were resolved and reported.
\end{abstract}

(c) 2016 Elsevier Ltd. All rights reserved.

\section{Introduction}

Owing to their potential ability to give $\sigma$-butadienyl derivatives as the products of the oxidative addition of organic halides or halogens, palladacyclopentadienyl complexes have often been studied from the catalytic [1] and stoichiometric [2] point of view. The reaction entails the $\mathrm{Pd}(\mathrm{II})-\mathrm{Pd}(\mathrm{IV})-\mathrm{Pd}(\mathrm{II})$ conversion which was by far less studied than that involving the $\operatorname{Pd}(0)-P d(I I)$ process [3]. For such a reason we think that any attempts at shedding light on the still debated Pd(IV) intermediate should be of remarkable interest. Moreover, the possibility to obtain dienes with a Z-Z configuration by further addition of organic halides or halogens to the $\sigma$-butadienyl complexes extends the range of synthetic available methodologies based on acetylene coupling [4]. In this respect we have recently published three studies of the reactivity of some palladacyclopentadienyl complexes bearing isocyanides, phosphoquinolines and pyridylthioethers as ancillary ligands with halogens and interhalogens. In any case we have obtained interesting results. In the first study we have measured the rates of

\footnotetext{
* Corresponding author. Tel.: +390412348655.

E-mail address: cano@unive.it (L. Canovese).
}

intramolecular conversion of the intermediate trans-diiodo palladium(IV) into the cis-diisocyanide-tetramethyl pallada-1-iodobuta-1,3-diene-1,2,3,4-tetracarboxylate and its subsequent isomerisation to the trans-isomer $[2 \mathrm{~d}]$. The second investigation was characterized by the peculiar evolution of the initially formed $\sigma$-butadienyl complex, consisting in an intermolecular attack of the phosphorus originally coordinated to the metal on the $\mathrm{sp}^{2}$ carbon of the $\sigma$-butadienyl fragment with the consequent widening of the phosphoquinoline coordinating ring and the unexpected final formation of a zwitterionic species (Scheme 1) [2e].

Finally, we have studied the palladacyclopentadienyl complexes bearing pyridylthioethers as spectator ligands reacting with halogens and interhalogens to give the $\sigma$-butadienyl derivatives as final products. However, in the case of interhalogens the final product was not the predictable one but rather the less thermodynamically stable species [2h].

The intriguing aspects of these studies prompted us to undertake a further investigation on palladacyclopentadienyl complexes bearing thio-quinoline based spectator ligands reacting with halogens and interhalogens. In the present study, we tried to establish how the combination between the structure of the ancillary ligand 


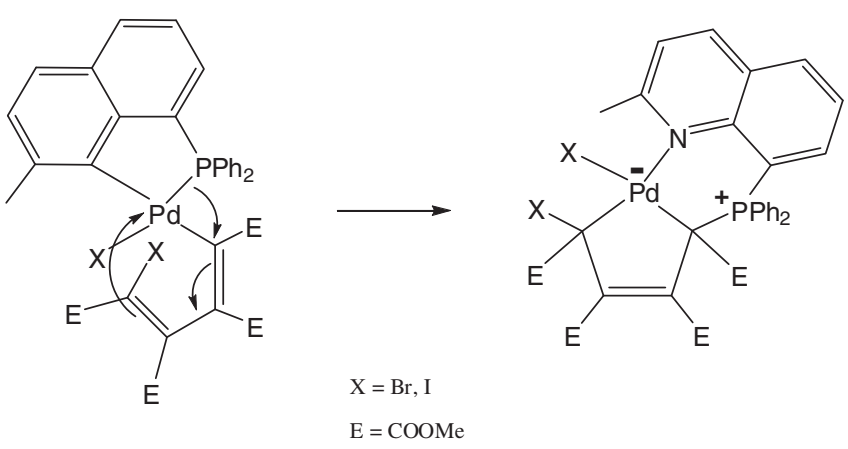

Scheme 1. Intermolecular attack of the phosphorus on the $\mathrm{sp}^{2}$ carbon of the $\sigma$ butadienyl fragment and final formation of a zwitterionic species [2e].

and the sulfur atom might influence the overall reactivity of the complexes themselves and investigate whether the formation of the less stable $\sigma$-butadienyl and/or zwitterionic species can be considered a general trend. Furthermore, we have studied the kinetics in detail and surmised a plausible mechanism for the reaction between the $\sigma$-butadienyl complexes and $\mathrm{Br}_{2}$ in excess leading to the extrusion of 1,4-dibromobuta-1,3-diene.

The ligands, the investigated complexes, the halogens, the interhalogens and the products of the oxidative addition are reported in Scheme 2.

\section{Results and discussion}

\subsection{General remarks}

The ligands TMQ TTBQ [5], TMQ-Me [6], TTBQ-Me [7], the polymer $\left[\mathrm{PdC}_{4}(\mathrm{COOMe})_{4}\right]_{n}$ [8] and complex 1c [6] were obtained according to published protocols. The complexes $\mathbf{1 a}, \mathbf{b}, \mathbf{d}$ are newly synthesized species and were obtained by adding a small excess of the appropriate ligand to the polymer $\left[\mathrm{PdC}_{4}(\mathrm{COOMe})_{4}\right]_{n}$ under inert atmosphere in anhydrous acetone. The formation of the complexes 1a-d is deduced from their NMR spectra which display all the signals of the ligands and carboxymethyl groups at different frequencies than those of the uncoordinated ones. In particular, owing to the ditopicity of the spectator ligands, the COOMe groups resonate as four distinct signals within 3.5-4.0 ppm (see Section 4 and Fig. 1 SM in Supplementary Material).

\subsection{Reactivity of complexes $\mathbf{1 a - d}$ with $\mathrm{I}_{2}$ and $\mathrm{Br}_{2}$}

Addition under inert atmosphere of a stoichiometric amount of $\mathrm{I}_{2}$ or $\mathrm{Br}_{2}$ to a solution of complexes $\mathbf{1 a - c}$ in anhydrous $\mathrm{CH}_{2} \mathrm{Cl}_{2}$ yields the $(\mathrm{Z}, \mathrm{Z})-\sigma$-butadienyl derivatives $\mathbf{2 a - d}$ or $\mathbf{3 a - d}$, respectively. The reactions are fast and complete as can be seen from the immediate decolorization of the reaction mixture. A stoichiometric amount of halogens is crucial since an excess especially in the case of $\mathrm{Br}_{2}$, might induce a further reaction with the extrusion of the 1,4-dihalobuta-1,3-diene (see later). The $\sigma$-butadienyl complexes $\mathbf{2 a - d}$ and $\mathbf{3 a - d}$ are stable and isolable and their structure is inferred from the ${ }^{1} \mathrm{H}$ and ${ }^{13} \mathrm{C}$ NMR spectra in which again, all the signals of the starting complexes 1a-d are detected at shifted frequencies. Remarkably, the position of the pyridine proton $\mathrm{H}^{2}$ in the case of complexes $\mathbf{2 a - b}$ and $\mathbf{3 a - b}$ (ligands TMQ and TTBQ) and that of the terminal butadienyl carbon coordinated to the halide in all the formed complexes is particularly diagnostic $[6,9 a]$. Therefore, the structure of the complexes is immediately recognized since the low-field resonance of the terminal butadienyl carbon ( $\sim 100 \mathrm{ppm}, \mathrm{X}=\mathrm{I} ; \sim 150 \mathrm{ppm}, \mathrm{X}=\mathrm{Br}$ ), of the quinolinic $\mathrm{H}^{2}(10.15-10.25 \mathrm{ppm}, \mathrm{X}=\mathrm{I}$; $9.85-9.96 \mathrm{ppm}, \mathrm{X}=\mathrm{Br})$ and to a lesser extent of the pyridine methyl substituent (complexes 2c-d, 3c-d), indicate the exclusive formation the isomer bearing the halide trans to the pyridine nitrogen (see Scheme 2, Section 4 and Fig. 2 SM in Supplementary Material). Owing to the position of the $\sigma$-butadienyl fragment and the substituent at sulfur which can occupy the same or opposite side of the main plane of the complexes two rotamers (exo and endo) are possible. The existence of the rotamers in different concentration due to the different stability can be revealed by low temperature NMR, as can be seen in the spectrum of complex $2 \mathbf{a}$ recorded at $223 \mathrm{~K}$ (see Fig. 3 SM in Supplementary Material). The isomeric choice (halide cis to pyridine nitrogen) and the existence of rotamers was confirmed by the resolved solid state structure of the exo rotamer of complex 3a reported in Fig. 1 (the solid state structure will be discussed later).

In summary, the thioquinoline palladacyclopentadienyl complexes behave very similarly to the analogous pyridylthioether derivatives when reacting with halogens. In the Supplementary Material (Fig. 4 SM) we report the results of a computational study related to the energy involved in the above described reactions which parallels and confirms the results we and other authors have obtained in previously published articles [2b,2h]. In particular it is noteworthy that:

(i) The $\sigma$-butadienyl derivatives are more stable than the starting reagents (Fig. 4a, b SM, [2b,2h]).

(ii) The reactions of the palladacyclopentadienyl complexes with $\mathrm{Br}_{2}$ are thermodynamically favored with respect to those with $\mathrm{I}_{2}$ (Fig. 4a, b SM, [2b,2h]).

(iii) Owing to the energy difference between the two possible isomers, the opening of the pentadienyl ring only occurs trans to the thioquinoline sulfur with the consequent formation of only one regioisomer (Fig. 4c, d SM, [2h]).

\subsection{Reactivity of complexes 1a-d with $\mathrm{ICl}$ and $\mathrm{IBr}$}

The thioquinoline derivatives react with the interhalogens $\mathrm{ICl}$ and $\mathrm{IBr}$ to give selectively the isomers bearing $\mathrm{Cl}$ and $\mathrm{Br}$, respectively coordinated to palladium, whereas I is in any case obviously bound to the terminal dienyl carbon. Remarkably, the displacement of pentadienyl ring again takes place trans to the thioquinoline sulfur (see Scheme 2). Therefore, only one of the four possible isomers is obtained in any case considered and these findings confirm the previously observed results obtained with the pyridylthioether derivatives [ $2 \mathrm{~h}]$.

The ${ }^{1} \mathrm{H}$ NMR spectra of the complexes $\mathbf{4}$ and $\mathbf{5}$ confirms the nature of the isomers since the resonance of the quinolyl $\mathrm{H}^{2}$ in the interval 9.64-9.74 and 9.85-9.96 ppm is typical of a complex bearing a chloride or bromide cis to quinoline ring, respectively. [[2h] and Refs. therein] (see also Section 4 and Fig. 6 SM in Supplementary Material section). Moreover the ${ }^{13} \mathrm{C}$ low-field resonance of the terminal butadienyl carbon at ca. $100 \mathrm{ppm}$ $(=\underline{\mathrm{C}}-\mathrm{I})$ is a further indication that the complexes with the bromide or chloride coordinated to palladium are formed.

In the case of complex $\mathbf{4 a}$ we were able to obtain crystals suitable for a diffractometric determination of its solid state structure which is reported in Fig. 2. Again, the structure will be discussed further on.

The regioisomers $\mathbf{4 a - d}$ are stable and isolable and a slow isomerization process is detectable only after different but in any case significant time intervals.

As for the derivatives obtained by adding $\mathrm{IBr}$ to $\mathbf{1 a - d}$ complexes, only the species $\mathbf{5 a}, \mathbf{b}, \mathbf{d}$ can be separated pure from the reaction mixture. However the latter display an enhanced tendency to isomerise to the most stable isomer (i.e. with I 

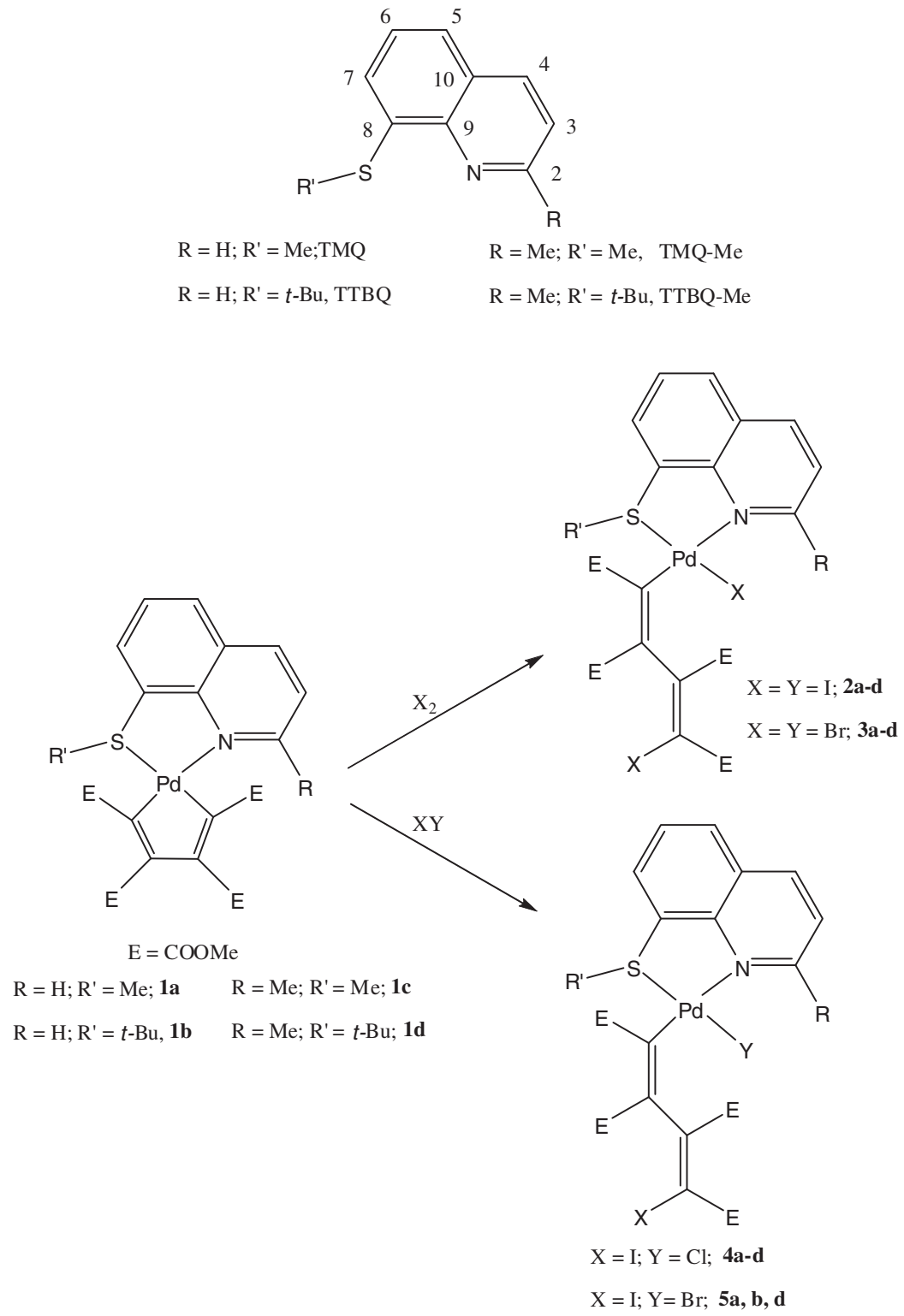

Scheme 2. Ligands, starting complexes, halogens, interhalogens and reaction products.

coordinated to palladium) with respect to that of the ICl derivatives. This tendency is particularly remarkable in the case of the reaction between $\mathbf{1 c}$ and $\mathrm{IBr}$ when, complex $\mathbf{5 c}$ cannot be separated pure.

We surmise that the formation of $\mathbf{4 a - d}$ and $\mathbf{5 a}, \mathbf{b}, \mathbf{d}$ is kinetically controlled as can be deduced from a detailed computational study whose results are shown in Fig. 3 and in Fig. 7 SM in Supplementary.

It is apparent that in these cases the formation of the less thermodynamically stable regioisomer is promoted by the smaller energy required to achieve the Transition State (TS), owing to the hardness of the $\mathrm{Pd}(\mathrm{IV})$ which favors the $\mathrm{Pd}-\mathrm{Cl}$ (reaction with $\mathrm{ICl}$ ) or the $\mathrm{Pd}-\mathrm{Br}$ (reaction with $\mathrm{IBr}$ ) bond. Remarkably, the energy gap required for the formation of the TS yielding the complex $\mathbf{4 a}$ is considerably higher than that required for the $\mathbf{5 a}$ derivative.

Notably, the lower stability of the isomers $\mathbf{4}$ and $\mathbf{5}$ justifies the successive slow rearrangement into the species $\mathbf{4}^{\prime}$ and $\mathbf{5}^{\prime}$ bearing iodide coordinated to palladium as experimentally observed in the case of the complexes $\mathbf{4}$ and $\mathbf{5}$.

\subsection{Reactivity of type 1 complexes with $\mathrm{Br}_{2}$ in excess}

The extrusion of organic fragments coordinated to transition metals using molecular halogens is a well established synthetic strategy. In particular our and other research groups have been involved in the reaction between halogens and pallada- $\sigma$-butadienyl complexes yielding di-halobutadiene species with Z-Z structure which are easily accessible for further synthetic strategy $[2 \mathrm{~h}, 4]$. In this respect, we have recently reported a hypothetical mechanism for the reaction between the pyridylthioether pallada- $\sigma$-butadienyl bromide complexes and $\mathrm{Br}_{2}$ yielding the extrusion of 1,4-dibromobuta-1,3-diene (DBBD) [2h]. In order to determine the intimate mechanism governing this sort of reactions, we have carried out a more detailed mechanistic investigation involving the thioquinoline derivatives reported in the present study. The reaction, the starting species, the reaction products and the suggested intermediates are represented in the following Scheme 3.

It is noteworthy that the DBBD compound can be easily separated by extraction with diethylether from the dried reaction 


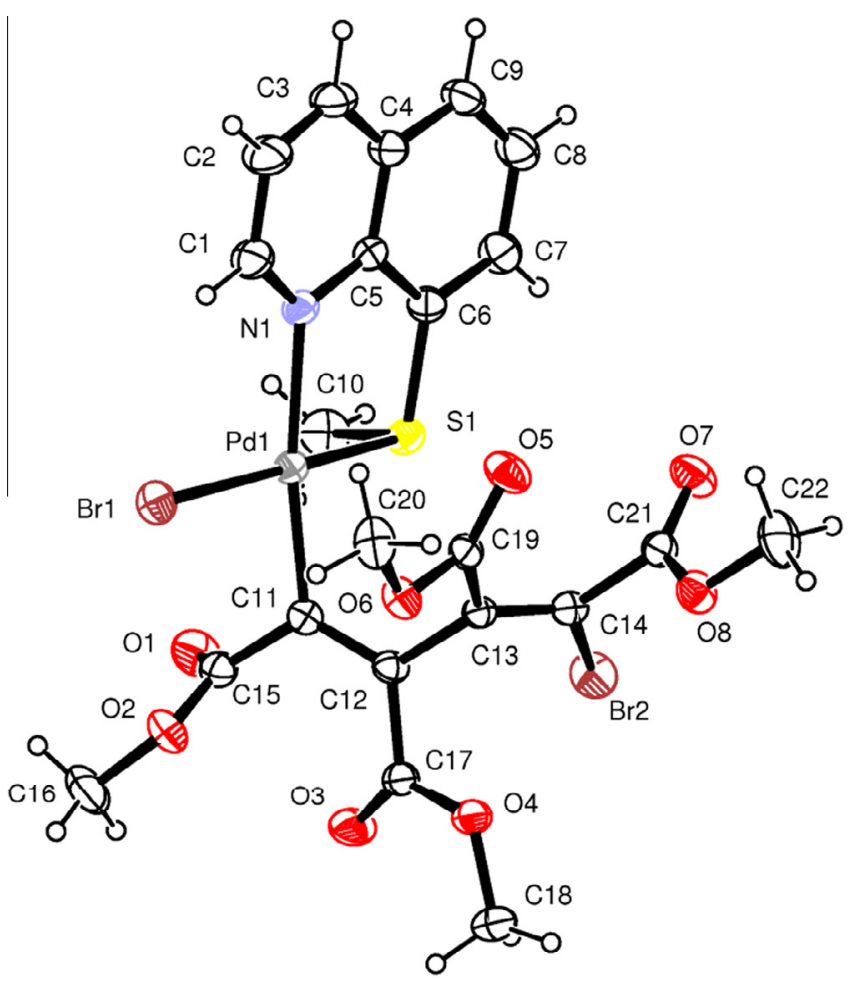

Fig. 1. ORTEP view of complex 3a showing the thermal ellipsoids at 30\% probability level.

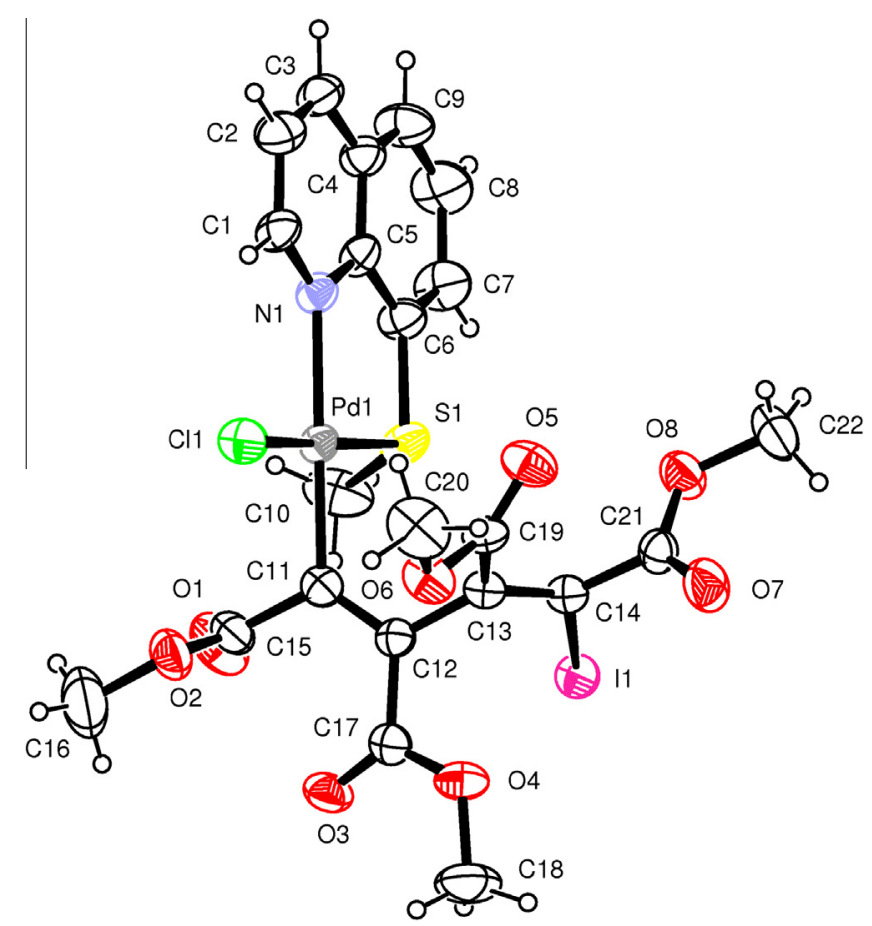

Fig. 2. ORTEP view of complex $\mathbf{4 a}$ showing the thermal ellipsoids at $30 \%$ probability level.

mixture, whereas the complexes $\mathbf{6 a}, \mathbf{c}, \mathbf{d}$ in the residual are easily characterized.

From a preliminary screening, complex $\mathbf{3 c}$ emerged as the most suitable complex for a detailed mechanistic study thank to the clearness of the ${ }^{1} \mathrm{H}$ NMR signals and the measurable reaction rates recorded under variable bromine concentrations. (see Figs. 9 SM and 10 SM in Supplementary).

As can be deduced from the Figs. 9 SM and 10 SM the single reaction can be described by a first-order process of the type:

$[\mathbf{3 c}]=[\mathbf{3} \boldsymbol{c}]_{0} e^{-k_{\text {obs }} t}$

The dependence between the ensuing $k_{\mathrm{obs}}$ and $\left[\mathrm{Br}_{2}\right]$ is linear with no statistically significant intercept and obeys to the equation:

$k_{\mathrm{obs}}=k_{\mathrm{II}}\left[\mathrm{Br}_{2}\right]$

Under the reasonable hypothesis that complexes $\mathbf{3 a}$ and $\mathbf{3 d}$ react analogously, in order to obtain a complete view of the problem we have carried out a kinetic analysis based on a single measurement by reacting the above cited complexes with a tenfold excess of $\mathrm{Br}_{2}$ and calculated the $k_{\mathrm{II}}$ by dividing the fitted $k_{\mathrm{obs}}$ by the bromine concentration (see Fig. 11 SM in Supplementary). The resulting $k_{\mathrm{II}}$ values are reported in the following Table 1.

Furthermore, we have computed the energies involved in the process under study (see Fig. 12 SM in Supplementary). Since no intermediate is experimentally detectable and on the basis of the calculated energies, we surmise that the steady state approximation $\left(k_{r}+k_{2} \gg k_{f}\right)$ can be applied to the process described in Scheme 2 .

In this case the rate law becomes:

$-\frac{d[3]}{d t}=k_{I I}[3]\left[B r_{2}\right] \quad$ with $k_{\mathrm{II}}=\frac{k_{f} k_{2}}{k_{r}+k_{2}}$

The above suggested steady state approximation fits nicely with the experimental results summarized in Table 1. The bulky complex $\mathbf{3 d}$ reacts slower than $\mathbf{3 a}$ and $\mathbf{3 c}$, the latter being the fastest. It is well known that the methyl substituent in position 2 of the pyridine ring in ligands of the type $\mathrm{N}-\mathrm{S}$ or $\mathrm{N}-\mathrm{P}$ induces a distortion on the main plane of the square planar complexes which favors the attack to the central metal [6,9]. Thus, the attack at the distorted complex 3c gives the less energetic intermediate and therefore $\mathbf{3 c}$ becomes the most reactive species. As similar conclusion is suggested by the reactivity of complex 3d since its measurable reaction rate, though the lowest, depends on the distortion of its spectator ligand TTBQ-Me. Remarkably, the reaction rate of the bulky but undistorted complex $\mathbf{3 b}$ is very low and complicated by incipient decomposition.

The computational results related to this sort of reaction are reported in Fig. 12 SM in Supplementary.

\subsection{Reactivity of type 1 complexes with $I_{2}$ in excess}

The experimentally observed inertness of the complexes 2 toward oxidative addition of $\mathrm{I}_{2}$ somehow matches with the computational results. As a matter of fact, only the most reactive complex $2 c$ reacts with $I_{2}$ in excess to give in some days a reaction mixture in which some unreacted starting complex can still be detected. As can be deduced from the calculated energies, the gaps among the starting complexes, the intermediate and the TS are higher than those previously calculated for complexes 3 reacting with $\mathrm{Br}_{2}$. Moreover, the small difference in energy between the starting complex and the reaction products justifies the experimentally observed final equilibrium mixture (see Fig. $13 \mathrm{SM}$ in Supplementary).

\subsection{Crystal structure determinations}

ORTEP [10] views of the isostructural complexes $\mathbf{3 a}$ and $\mathbf{4 a}$ are shown in Figs. 1 and 2. A selection of bond distances and angles 


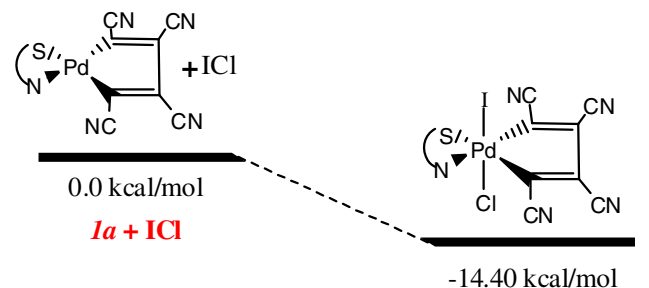

INTERMEDIATE

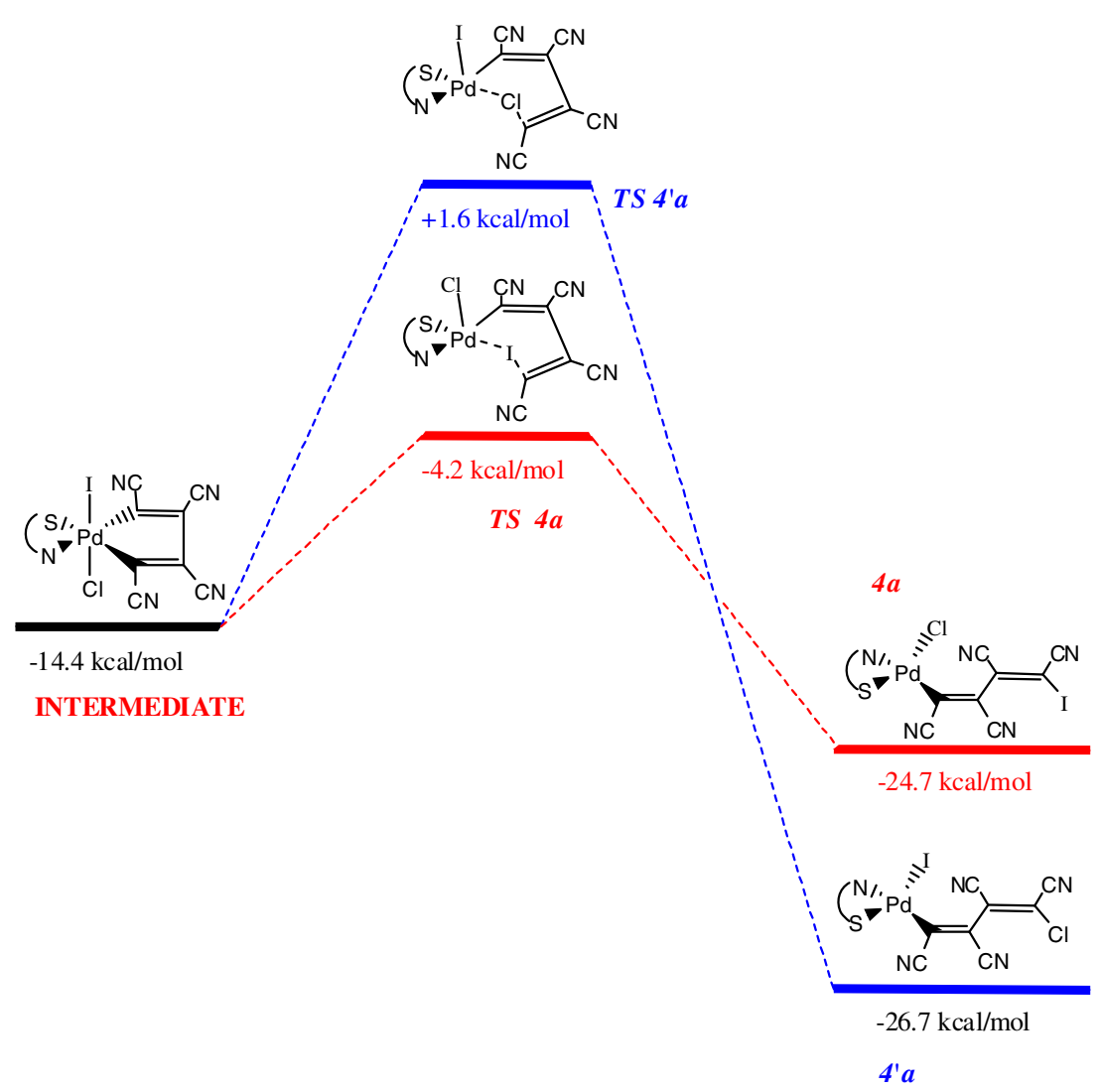

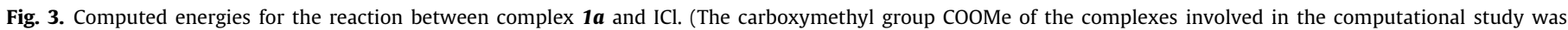
substituted by the less disordered $\mathrm{CN}$ fragment. The $\mathrm{CN}$ derivatives maintain the same labels as the original ones albeit in italics).

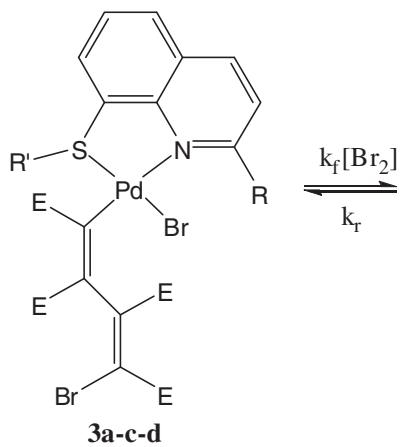

3a-c-d<smiles>CCCS1(Br)C=C2C=CC=C(P)N2[Pb]1(Br)C(F)=C(F)C(F)=C(F)Br</smiles>

In

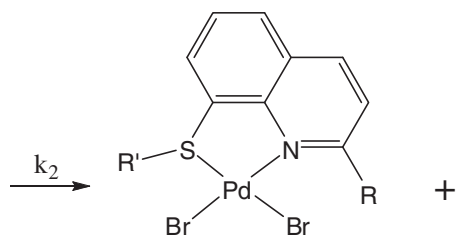

6a-c-d<smiles>FC(Br)=C(F)C(F)=C(F)Br</smiles>

DBBD

(INTERMEDIATE)

Scheme 3. Reaction of complexes $\mathbf{3 a - c - d}$ with the $\mathrm{Br}_{2}$ in excess: involved species and suggested intermediate.

is given in Table $1 \mathrm{SM}$ (Supplementary Material). Both complexes adopt similar structures except for the presence of two $\mathrm{Br}$ atoms in complex $3 a$ instead of a $\mathrm{Cl}$ atom bonded to a central Pd1 and an I atom on the butadiene substituted ligand in complex $\mathbf{4 a}$.
The geometry around the Pd centers is slightly distorted square planar where the four positions are occupied by a halogen atom, $\mathrm{Br}$ in $\mathbf{3 a}$ or $\mathrm{Cl}$ in $\mathbf{4 a}$, the nitrogen and the sulfur of the thio-methylquinoline ligand and the carbon $C_{\alpha}$ of the $1,2,3,4$ tetrakis(methoxy- 
Table 1

Measured rate constants $\left(k_{I I}\right)$ for the reaction: $\mathbf{3}+\mathrm{Br}_{2} \rightarrow \mathbf{6}+$ DBBD.

\begin{tabular}{ll}
\hline Complex & $k_{I I}\left(\mathrm{~mol}^{-1} \mathrm{dm}^{3} \mathrm{~s}^{-1}\right)$ \\
\hline 3c & $(1.6 \pm 0.2) \times 10^{-2}$ \\
3a & $(1.11 \pm 0.02) \times 10^{-3}$ \\
3d & $(1.66 \pm 0.03) \times 10^{-4}$ \\
\hline
\end{tabular}

carbonyl) buta-1,3-diene-4- $\mathrm{Br}$ (or I)-1-yl ligand. The $\mathrm{C} 11=\mathrm{C} 12-$ $\mathrm{C} 13=\mathrm{C} 14$ buta-1,3-diene moieties display anti-clinal conformations with torsion angles of $-118.3(3)^{\circ}$ and $-109(1)^{\circ}$ in $\mathbf{3 a}$ and 4a, respectively.

Both complexes, in the crystal packings, display short Halogen $\cdots$ Oxygen contacts [11-13]: $\operatorname{Br} 2 \cdots 03(-x+1,-y,-z)=3.209$ (2) $\AA \AA$ in 3a and $\mathrm{I} 1 \cdots \mathrm{O} 3(1-x, 1-y, 2-z)=2.965(8) \AA$ in $4 \mathbf{a}$.

\section{Conclusion}

We have synthesized some palladacyclopentadienyl derivatives bearing differently substituted thioquinolines as spectator ligands. The palladacyclopentadienyl complexes were reacted with halogens $\left(\mathrm{I}_{2}\right.$ and $\left.\mathrm{Br}_{2}\right)$ and interhalogens ( $\mathrm{ICl}$ and $\mathrm{IBr}$ ) to give the thioquinoline palladium $\sigma$-butadienyl species which in two cases were characterized by the diffractometric determination of their solid state structures and in all cases by ${ }^{1} \mathrm{H}$ and ${ }^{13} \mathrm{C}$ NMR, IR and elemental analyses. The addition of interhalogens to compounds 1 yields the less thermodynamically stable products. This result parallels the one we obtained in a previous work [2h] and in this respect it is established that the reaction progress is dictated by the nature of the atoms in the ancillary ligand ( $\mathrm{N}$ and $\mathrm{S}$ ) instead of the quinolinic scaffold of the ligands themselves [2e]. We have also studied in detail the extrusion of the 1,4-dibromobuta-1,3diene (DBBD) by addition of $\mathrm{Br}_{2}$ in excess to complexes of type 3 and proposed an overall mechanism involving a steady state approximation for the $\mathrm{Pd}(\mathrm{IV})$ intermediate.

\section{Experimental}

\subsection{Solvents and reagents}

All the following distillation processes were carried out under inert atmosphere (Argon). Acetone and $\mathrm{CH}_{2} \mathrm{Cl}_{2}$ were distilled over 4 Å molecular sieves and $\mathrm{CaH}_{2}$, respectively. THF was carefully dried by distillation over $\mathrm{Na}$ /benzoquinone. All other chemicals were commercially available grade products and were used as purchased.

\subsection{IR, NMR, UV-Vis measurements and elemental analysis}

The IR, ${ }^{1} \mathrm{H},{ }^{13} \mathrm{C}$ and ${ }^{31} \mathrm{P}$ NMR spectra were recorded on a PerkinElmer Spectrum One spectrophotometer and on a Bruker 300 Avance spectrometer, respectively. UV-Vis spectra were taken on a Perkin-Elmer Lambda 40 spectrophotometer equipped with a Perkin-Elmer PTP6 (Peltier temperature programmer) apparatus.

The elemental analysis of the synthesized complexes was carried out using an Elementar CHN "CUBO micro Vario" analyzer.

\subsection{Kinetic measurements by ${ }^{1} \mathrm{H} N \mathrm{NR}$}

The reactions between complexes 3 and $\mathrm{Br}_{2}$ were studied by ${ }^{1} \mathrm{H}$ NMR by dissolving the complex under study in $0.6 \mathrm{ml}$ of $\mathrm{CDCl}_{3}$ ([Complex $]_{0} \approx 1.2 \times 10^{-2} \mathrm{~mol} \mathrm{dm}^{-3}$ ), adding microaliquots of a concentrated $\mathrm{CDCl}_{3}$ solution of bromine $\left(\left[\mathrm{Br}_{2}\right] \approx 1.2 \times 10^{-1}\right.$ $\mathrm{mol} \mathrm{dm^{-3 }}$ ) and monitoring the signal for the disappearance of the starting complex and the concomitant appearance of the final products.

\subsection{Data analysis}

Non linear regression analysis of the data related to kinetics measurements was performed by locally adapted routines written in the ORIGIN ${ }^{\circledR} 7.5$ environment.

\subsection{Crystal structure determinations}

The crystal data of compounds $\mathbf{3 a}$ and $\mathbf{4 a}$ were collected at room temperature using a Nonius Kappa CCD diffractometer with graphite monochromated Mo K $\alpha$ radiation. The data sets were integrated with the Denzo-SMN package [14] and corrected for Lorentz, polarization and absorption effects (SORTAV) [15]. The structures were solved by direct methods using SIR97 [16] system of programs and refined using full-matrix least-squares with all non-hydrogen atoms anisotropically and hydrogens included on calculated positions, riding on their carrier atoms.

The crystal of 4a contains disordered molecules of solvent in the asymmetric unit: a molecule of $\mathrm{CH}_{2} \mathrm{Cl}_{2}$ which was refined with occupancy of $1 / 2$ and a molecule of water which was split over two positions and refined with occupancy of $1 / 2$ each.

All calculations were performed using SHELXL-97 [17] and PARST [18] implemented in wingx [19] system of programs. The crystal data are given in Table 2 SM (Supplementary Material).

\subsection{Computational details}

In order to save computer time we have replaced the carboxymethyl group COOMe by the less disordered $\mathrm{CN}$ fragment in the complexes under study and in the following discussion the $\mathrm{CN}$ derivatives will maintain the same labels as the original complexes albeit in italics (4a, $\mathbf{5 a}$ becomes $\mathbf{4 a}$ and $\mathbf{5 a}$, respectively).

We have undertaken a detailed computational study in order to verify the consistency, if any, between the calculated results and our experimental observations in the case of complexes $\mathbf{4 a} / \mathbf{4} \boldsymbol{a}^{\prime}$ and $\mathbf{5 a} / \mathbf{5} \boldsymbol{a}^{\prime}$.

Remarkably, our experimental results were not in contrast with the computational study carried out by the GAUSSIAN 09 program [20] and despite the implicit limitations $\left(\Delta \Delta G^{\circ} \approx \pm 2 \mathrm{kcal} / \mathrm{mol}\right.$ and the replacement of COOMe with $\mathrm{CN}$ groups), we have obtained a confirmation and hence a possible explanation of the observed trend.

The geometrical optimization of the complexes was carried out without symmetry constraints, using the hyper-GGA functional MO6 [21,22], in combination with polarized triple- $\zeta$-quality basis sets (LAN2TZ(f)) $[23,24]$ and relativistic pseudopotential for the Pd atoms, a polarized double- $\zeta$-quality basis sets (LANL2DZdp) [25] with diffuse functions for the halogen atoms and a polarized double- $\zeta$-quality basis sets $(6-31 G(d, p))$ for the other elements. Solvent effects (acetonitrile, $\varepsilon=37.5$ ) were included using CPCM [26,27].

The "restricted" formalism was applied in all the calculations. The zero-point vibrational energies and thermodynamic parameters were obtained [28] by means of the stationary points characterized by IR simulation.

All the computational work was carried out on Intel based x8664 workstations.

\subsection{Synthesis of the complexes}

As already stated the ligands TMQ TTBQ [5], TMQ-Me [6], TTBQ-Me [7], the polymer $\left[\mathrm{PdC}_{4}(\mathrm{COOMe})_{4}\right]_{n}[8]$ and the complex 1c [6] have been synthesized according to published procedures. The synthesis and characterization of all the other complexes are reported in the following experimental part. The atom numbering 
scheme related to the complexes described in this section is established in Scheme 2.

\subsubsection{Synthesis of complex 1a}

A solution of $0.20 \mathrm{~g}(0.51 \mathrm{mmol})$ of complex $\left[\mathrm{PdC}_{4}(\mathrm{COOMe})_{4}\right]_{n}$ and $0.0999 \mathrm{~g}(0.57 \mathrm{mmol})$ of TMQ in $20 \mathrm{ml}$ of anhydrous acetone were stirred under inert atmosphere $(\mathrm{Ar})$ for $1 \mathrm{~h}$. The solution was then evaporated to small volume (ca. $5 \mathrm{ml}$ ) under vacuum.

Complex 1a was precipitated by slow addition of diethylether, filtered off on a gooch, washed with diethylether and n-pentane and dried under vacuum. $0.249 .8 \mathrm{~g}$ (yield $83 \%$ ) of the title complex was obtained as yellow microcrystalline solid.

${ }^{1} \mathrm{H} \mathrm{NMR}\left(300 \mathrm{MHz}, \mathrm{CDCl}_{3}, T=298 \mathrm{~K}, \mathrm{ppm}\right) \delta: 2.87\left(\mathrm{~s}, 3 \mathrm{H}, \mathrm{SCH}_{3}\right)$, $3.72\left(\mathrm{~s}, 3 \mathrm{H}, \mathrm{OCH}_{3}\right), 3.74\left(\mathrm{~s}, 3 \mathrm{H}, \mathrm{OCH}_{3}\right), 3.77\left(\mathrm{~s}, 3 \mathrm{H}, \mathrm{OCH}_{3}\right), 3.79(\mathrm{~s}$, $\left.3 \mathrm{H}, \mathrm{OCH}_{3}\right), 7.63\left(\mathrm{dd}, 1 \mathrm{H}, J=8.3,5.1 \mathrm{~Hz}, \mathrm{H}^{3}\right), 7.73(\mathrm{dd}, 1 \mathrm{H}, J=8.2$, $7.3 \mathrm{~Hz}, \mathrm{H}^{6}$ ), 8.01 (d, $1 \mathrm{H}, J=8.2,1.3 \mathrm{~Hz}, \mathrm{H}^{5}$ ), 8.11 (dd, $1 \mathrm{H}, J=7.3$, $\left.1.3 \mathrm{~Hz}, \mathrm{H}^{7}\right), 8.46\left(\mathrm{dd}, 1 \mathrm{H}, J=8.3,1.5 \mathrm{~Hz}, \mathrm{H}^{4}\right), 9.00(\mathrm{dd}, 1 \mathrm{H}, J=5.1$, $\left.1.5 \mathrm{~Hz}, \mathrm{H}^{2}\right)$.

${ }^{13} \mathrm{C}\left\{{ }^{1} \mathrm{H}\right\}-\mathrm{NMR}\left(\mathrm{CDCl}_{3}, T=298 \mathrm{~K}, \mathrm{ppm}\right) \delta: 27.5\left(\mathrm{CH}_{3}, \mathrm{SCH}_{3}\right), 52.1$ $\left(\mathrm{CH}_{3}, \mathrm{OCH}_{3}\right), 51.2\left(\mathrm{CH}_{3}, \mathrm{OCH}_{3}\right), 51.4\left(\mathrm{CH}_{3}, \mathrm{OCH}_{3}\right), 51.4\left(\mathrm{CH}_{3}\right.$, $\left.\mathrm{OCH}_{3}\right), 122.9\left(\mathrm{CH}, \mathrm{C}^{3}\right), 128.3\left(\mathrm{CH}, \mathrm{C}^{6}\right), 130.3\left(\mathrm{C}, \mathrm{C}^{10}\right), 130.9(\mathrm{CH}$, $\left.\mathrm{C}^{5}\right), 131.9\left(\mathrm{C}, \mathrm{C}^{8}\right), 136.4\left(\mathrm{CH}, \mathrm{C}^{7}\right), 139.9\left(\mathrm{CH}, \mathrm{C}^{4}\right), 143.8(\mathrm{C}, \mathrm{C}=\mathrm{C})$, $148.7(\mathrm{C}, \mathrm{C}=\mathrm{C}), 149.0\left(\mathrm{C}, \mathrm{C}^{9}\right), 154.3\left(\mathrm{CH}, \mathrm{C}^{2}\right), 158.6(\mathrm{C}, \mathrm{C}=\mathrm{C})$, $163.8(C, C=0), 164.8(C, C=0), 169.2(C, C=C), 173.2(C, C=0)$, $174.1(\mathrm{C}, \mathrm{C}=\mathrm{O})$.

IR ( $\mathrm{KBr}$ pellets): $v_{\mathrm{C}=\mathrm{O}} 1712,1689 \mathrm{~cm}^{-1}$.

Anal. Calc. for $\mathrm{C}_{22} \mathrm{H}_{21} \mathrm{NO}_{8} \mathrm{PdS}$ : C, 46.69; $\mathrm{H}, 3.74 ; \mathrm{N}, 2.48$. Found: C, $46.81 ; \mathrm{H}, 3.62 ; \mathrm{N}, 2.33$.

The synthesis of the complexes $\mathbf{1 b} \mathbf{b} \mathbf{d}$ was carried out following a procedure similar to that described for complex $\mathbf{1 a}$.

\subsection{Synthesis of complex $\mathbf{1 b}$}

Dark yellow microcrystals. Yield $79 \%$.

${ }^{1} \mathrm{H}$ NMR (300 MHz, $\left.\mathrm{CDCl}_{3}, T=298 \mathrm{~K}, \mathrm{ppm}\right) \delta: 1.33$ (s, 9H, C $\left(\mathrm{CH}_{3}\right)_{3}, 3.71\left(\mathrm{~s}, 3 \mathrm{H}, \mathrm{OCH}_{3}\right), 3.72\left(\mathrm{~s}, 3 \mathrm{H}, \mathrm{OCH}_{3}\right), 3.76\left(\mathrm{~s}, 3 \mathrm{H}, \mathrm{OCH}_{3}\right)$, $3.79\left(\mathrm{~s}, 3 \mathrm{H}, \mathrm{OCH}_{3}\right), 7.59\left(\mathrm{dd}, 1 \mathrm{H}, J=8.3,5.1 \mathrm{~Hz}, \mathrm{H}^{3}\right), 7.72(\mathrm{dd}, 1 \mathrm{H}$, $\left.J=8.2,7.3 \mathrm{~Hz}, \mathrm{H}^{6}\right), 7.99\left(\mathrm{~d}, 1 \mathrm{H}, J=8.2,1.3 \mathrm{~Hz}, \mathrm{H}^{5}\right), 8.06(\mathrm{dd}, 1 \mathrm{H}$, $\left.J=7.3,1.3 \mathrm{~Hz}, \mathrm{H}^{7}\right), 8.45\left(\mathrm{dd}, 1 \mathrm{H}, J=8.3,1.5 \mathrm{~Hz}, \mathrm{H}^{4}\right), 8.96(\mathrm{dd}, 1 \mathrm{H}$, $\left.J=5.1,1.5 \mathrm{~Hz}, \mathrm{H}^{2}\right)$

${ }^{13} \mathrm{C}\left\{{ }^{1} \mathrm{H}\right\}-\mathrm{NMR}\left(\mathrm{CDCl}_{3}, \mathrm{~T}=298 \mathrm{~K}, \mathrm{ppm}\right) \delta: 30.5\left(\mathrm{CH}_{3}, \mathrm{SC}\left(\mathrm{CH}_{3}\right)_{3}\right)$, $51.1\left(\mathrm{CH}_{3}, \mathrm{OCH}_{3}\right), 51.2\left(\mathrm{CH}_{3}, \mathrm{OCH}_{3}\right), 51.4\left(\mathrm{CH}_{3}, \mathrm{OCH}_{3}\right), 51.4\left(\mathrm{CH}_{3}\right.$, $\left.\mathrm{OCH}_{3}\right), 58.0\left(\mathrm{C}, \mathrm{C}\left(\mathrm{CH}_{3}\right)_{3}\right), 122.7\left(\mathrm{CH}, \mathrm{C}^{3}\right), 127.8\left(\mathrm{CH}, \mathrm{C}^{6}\right), 127.9(\mathrm{C}$, $\left.\mathrm{C}^{10}\right), 129.8\left(\mathrm{C}, \mathrm{C}^{8}\right), 131.9\left(\mathrm{CH}, \mathrm{C}^{5}\right), 138.2\left(\mathrm{CH}, \mathrm{C}^{7}\right), 140.0\left(\mathrm{CH}, \mathrm{C}^{4}\right)$, $144.2(\mathrm{C}, \mathrm{C}=\mathrm{C}), 146.7(\mathrm{C}, \mathrm{C}=\mathrm{C}), 150.2\left(\mathrm{C}, \mathrm{C}^{9}\right), 153.6\left(\mathrm{CH}, \mathrm{C}^{2}\right)$, $160.4(C, C=C), 164.2(C, C=0), 164.3(C, C=0), 166.7(C, C=C)$ $173.2(C, C=0), 174.0(C, C=0)$.

IR ( $\mathrm{KBr}$ pellets): $v_{\mathrm{C}=\mathrm{O}} 1723,1695 \mathrm{~cm}^{-1}$.

Anal. Calc. for $\mathrm{C}_{25} \mathrm{H}_{27} \mathrm{NO}_{8} \mathrm{PdS}$ : C, 49.39; $\mathrm{H}, 4.48 ; \mathrm{N}, 2.30$. Found: C, 49.47; H, 4.52; N, 2.19 .

\subsection{Synthesis of complex 1 d}

Yellow microcrystals. Yield $80 \%$.

${ }^{1} \mathrm{H}$ NMR (300 MHz, CDCl3, T= $\left.298 \mathrm{~K}, \mathrm{ppm}\right) \delta: 1.17$ (s, 9H, C $\left.\left(\mathrm{CH}_{3}\right)_{3}\right), 2.92\left(\mathrm{~s}, 3 \mathrm{H}\right.$, quinoline- $\left.\mathrm{CH}_{3}\right), 3.29\left(\mathrm{bs}, 3 \mathrm{H}, \mathrm{OCH}_{3}\right), 3.68(\mathrm{~s}$, $\left.6 \mathrm{H}, \mathrm{OCH}_{3}\right), 3.83\left(\mathrm{bs}, 3 \mathrm{H}, \mathrm{OCH}_{3}\right), 7.45\left(\mathrm{~d}, 1 \mathrm{H}, J=8.4 \mathrm{~Hz}, \mathrm{H}^{3}\right), 7.60$ $\left(\mathrm{t}, 1 \mathrm{H}, J=7.7 \mathrm{~Hz}, \mathrm{H}^{6}\right), 7.90\left(\mathrm{~d}, 1 \mathrm{H}, J=7.7 \mathrm{~Hz}, \mathrm{H}^{5}\right), 7.93(\mathrm{~d}, 1 \mathrm{H}$, $\left.J=7.7 \mathrm{~Hz}, \mathrm{H}^{7}\right), 8.25\left(\mathrm{~d}, 1 \mathrm{H}, J=8.4 \mathrm{~Hz}, \mathrm{H}^{4}\right)$.

${ }^{13} \mathrm{C}\left\{{ }^{1} \mathrm{H}\right\}-\mathrm{NMR}\left(\mathrm{CDCl}_{3}, T=298 \mathrm{~K}, \mathrm{ppm}\right) \delta: 28.7\left(\mathrm{CH}_{3}\right.$, quinoline$\left.\mathrm{CH}_{3}\right), 30.3\left(\mathrm{CH}_{3}, \mathrm{SC}\left(\mathrm{CH}_{3}\right)_{3}\right), 50.9\left(\mathrm{CH}_{3}, \mathrm{OCH}_{3}\right), 51.0\left(\mathrm{CH}_{3}, \mathrm{OCH}_{3}\right)$, $51.1\left(\mathrm{CH}_{3}, \mathrm{OCH}_{3}\right), 51.4\left(\mathrm{CH}_{3}, \mathrm{OCH}_{3}\right), 55.8\left(\mathrm{C}, \mathrm{C}\left(\mathrm{CH}_{3}\right)_{3}\right), 123.6(\mathrm{CH}$, $\left.\mathrm{C}^{3}\right), 126.8\left(\mathrm{CH}, \mathrm{C}^{6}\right), 127.3\left(\mathrm{C}, \mathrm{C}^{10}\right), 129.0\left(\mathrm{C}, \mathrm{C}^{8}\right), 130.5\left(\mathrm{CH}, \mathrm{C}^{5}\right)$, $137.4\left(\mathrm{CH}, \mathrm{C}^{7}\right), 138.8\left(\mathrm{CH}, \mathrm{C}^{4}\right), 143.0(\mathrm{C}, \mathrm{C}=\mathrm{C}), 149.7\left(\mathrm{C}, \mathrm{C}^{9}\right), 150.0$ $(\mathrm{C}, \mathrm{C}=\mathrm{C}), 154.2(\mathrm{C}, \mathrm{C}=\mathrm{C}), 162.6(\mathrm{C}, \mathrm{C}=\mathrm{O}), 165.3\left(\mathrm{CH}, \mathrm{C}^{2}\right), 166.3(\mathrm{C}$, $C=0), 170.8(C, C=0), 171.9(C, C=C), 174.1(C, C=0)$.
IR ( $\mathrm{KBr}$ pellets): $v_{\mathrm{C}=\mathrm{O}} 1728,1700,1683 \mathrm{~cm}^{-1}$.

Anal. Calc. for $\mathrm{C}_{26} \mathrm{H}_{29} \mathrm{NO}_{8}$ PdS: C, 50.21; H, 4.70; N, 2.25. Found: C, 50.09; H, 4.57; N, 2.12.

\subsection{Synthesis of complex $\mathbf{2 a}$}

To $0.10 \mathrm{~g}(0.177 \mathrm{mmol})$ of complex 1a dissolved in $10 \mathrm{ml}$ of anhydrous $\mathrm{CH}_{2} \mathrm{Cl}_{2}, 0.0559 \mathrm{~g}$ ( $0.22 \mathrm{mmol}$ ) of $\mathrm{I}_{2}$ dissolved in $5 \mathrm{ml}$ of anhydrous $\mathrm{CH}_{2} \mathrm{Cl}_{2}$ was added under inert atmosphere (Ar). The resulting mixture instantaneously decolorized, was stirred for further 10 min and then concentrated to small volume under vacuum. Addition of diethyl ether induces the precipitation of a yellow solid which was filtered off on a gooch, washed with diethyl ether and $n$ pentane and dried under vacuum at RT. $0.1429 \mathrm{~g}$ (yield 99\%) of the title compound was obtained.

${ }^{1} \mathrm{H}$ NMR $\left(300 \mathrm{MHz}, \mathrm{CDCl}_{3}, T=298 \mathrm{~K}, \mathrm{ppm}\right) \delta: 3.06\left(\mathrm{~s}, 3 \mathrm{H}, \mathrm{SCH}_{3}\right)$, $3.73\left(\mathrm{~s}, 3 \mathrm{H}, \mathrm{OCH}_{3}\right), 3.75\left(\mathrm{~s}, 3 \mathrm{H}, \mathrm{OCH}_{3}\right), 3.84\left(\mathrm{~s}, 3 \mathrm{H}, \mathrm{OCH}_{3}\right), 3.87(\mathrm{~s}$, $\left.3 \mathrm{H}, \mathrm{OCH}_{3}\right), 7.57\left(\mathrm{dd}, 1 \mathrm{H}, J=8.3,5.1 \mathrm{~Hz}, \mathrm{H}^{3}\right), 7.74(\mathrm{dd}, 1 \mathrm{H}, J=8.2$, $\left.7.4 \mathrm{~Hz}, \mathrm{H}^{6}\right), 8.00\left(\mathrm{~d}, 1 \mathrm{H}, J=8.2,1.2 \mathrm{~Hz}, \mathrm{H}^{5}\right), 8.11(\mathrm{dd}, 1 \mathrm{H}, J=7.4$, $\left.1.2 \mathrm{~Hz}, \mathrm{H}^{7}\right), 8.41\left(\mathrm{dd}, 1 \mathrm{H}, J=8.3,1.5 \mathrm{~Hz}, \mathrm{H}^{4}\right), 10.24(\mathrm{dd}, 1 \mathrm{H}, J=5.1$, $\left.1.5 \mathrm{~Hz}, \mathrm{H}^{2}\right)$

${ }^{13} \mathrm{C}\left\{{ }^{1} \mathrm{H}\right\}-\mathrm{NMR}\left(\mathrm{CDCl}_{3}, \mathrm{~T}=298 \mathrm{~K}, \mathrm{ppm}\right) \delta: 29.1\left(\mathrm{CH}_{3}, \mathrm{SCH}_{3}\right), 51.8$ $\left(\mathrm{CH}_{3}, \mathrm{OCH}_{3}\right), 52.2\left(\mathrm{CH}_{3}, \mathrm{OCH}_{3}\right), 53.3\left(\mathrm{CH}_{3}, \mathrm{OCH}_{3}\right), 53.4\left(\mathrm{CH}_{3}\right.$, $\left.\mathrm{OCH}_{3}\right), 103.6(\mathrm{C}, \mathrm{C}=\mathrm{CI}), 123.7\left(\mathrm{CH}, \mathrm{C}^{3}\right), 128.0\left(\mathrm{CH}, \mathrm{C}^{6}\right), 130.4(\mathrm{C}$, $\left.\mathrm{C}^{10}\right), 130.6\left(\mathrm{CH}, \mathrm{C}^{5}\right), 133.2\left(\mathrm{C}, \mathrm{C}^{8}\right), 133.3(\mathrm{C}, \mathrm{C}=\mathrm{C}), 135.0\left(\mathrm{CH}, \mathrm{C}^{7}\right)$, $139.1\left(\mathrm{CH}, \mathrm{C}^{4}\right), 145.7(\mathrm{C}, \mathrm{C}=\mathrm{C}), 147.2\left(\mathrm{C}, \mathrm{C}^{9}\right), 154.7(\mathrm{C}, \mathrm{C}=\mathrm{C})$, $158.1\left(\mathrm{CH}, \mathrm{C}^{2}\right), 159.5(\mathrm{C}, \mathrm{C}=\mathrm{O}), 165.0(\mathrm{C}, \mathrm{C}=\mathrm{O}), 165.8(\mathrm{C}, \mathrm{C}=\mathrm{O})$, $172.4(\mathrm{C}, \mathrm{C}=\mathrm{O})$.

IR ( $\mathrm{KBr}$ pellets): $v_{\mathrm{C}=\mathrm{O}} 1727,1717,1705,1694 \mathrm{~cm}^{-1}$.

Anal. Calc. for $\mathrm{C}_{22} \mathrm{H}_{21} \mathrm{I}_{2} \mathrm{NO}_{8} \mathrm{PdS}$ : C, 32.24; $\mathrm{H}, 2.58 ; \mathrm{N}, 1.71$. Found: C, 32.30; H, 2.71; N, 1.63.

The synthesis of the complexes $\mathbf{2 b}$-d was carried out following a procedure similar to that described for complex $\mathbf{2 a}$.

\subsection{Synthesis of complex $\mathbf{2 b}$}

Yellow microcrystals. Yield 81\%.

${ }^{1} \mathrm{H}$ NMR (300 MHz, $\left.\mathrm{CDCl}_{3}, T=298 \mathrm{~K}, \mathrm{ppm}\right) \delta: 1.45$ (s, 9H, C $\left.\left(\mathrm{CH}_{3}\right)_{3}\right), 3.65$ (bs, $\left.6 \mathrm{H}, \mathrm{OCH}_{3}\right), 3.74\left(\mathrm{~s}, 3 \mathrm{H}, \mathrm{OCH}_{3}\right), 3.85(\mathrm{~s}, 3 \mathrm{H}$, $\left.\mathrm{OCH}_{3}\right), 7.54\left(\mathrm{dd}, 1 \mathrm{H}, J=8.3,5.0 \mathrm{~Hz}, \mathrm{H}^{3}\right), 7.73(\mathrm{dd}, 1 \mathrm{H}, J=8.2$, $\left.7.3 \mathrm{~Hz}, \mathrm{H}^{6}\right), 8.02\left(\mathrm{~d}, 1 \mathrm{H}, J=8.2 \mathrm{~Hz}, \mathrm{H}^{5}\right), 8.08\left(\mathrm{bd}, 1 \mathrm{H}, \mathrm{H}^{7}\right), 8.39(\mathrm{dd}$, $\left.1 \mathrm{H}, J=8.3,1.5 \mathrm{~Hz}, \mathrm{H}^{4}\right), 10.14$ (bs, $\left.1 \mathrm{H}, \mathrm{H}^{2}\right)$.

${ }^{13} \mathrm{C}\left\{{ }^{1} \mathrm{H}\right\}-\mathrm{NMR}\left(\mathrm{CDCl}_{3}, T=298 \mathrm{~K}, \mathrm{ppm}\right) \delta: 30.2\left(\mathrm{CH}_{3}, \mathrm{SC}\left(\mathrm{CH}_{3}\right)_{3}\right)$, $51.5\left(\mathrm{CH}_{3}, \mathrm{OCH}_{3}\right), 52.2\left(\mathrm{CH}_{3}, \mathrm{OCH}_{3}\right), 53.1\left(\mathrm{CH}_{3}, \mathrm{OCH}_{3}\right), 53.3\left(\mathrm{CH}_{3}\right.$, $\left.\mathrm{OCH}_{3}\right), 59.3\left(\mathrm{C}, \mathrm{C}\left(\mathrm{CH}_{3}\right)_{3}\right), 123.3\left(\mathrm{CH}, \mathrm{C}^{3}\right), 127.1\left(\mathrm{CH}, \mathrm{C}^{6}\right), 129.4(\mathrm{C}$, $\left.\mathrm{C}^{8}\right), 129.8\left(\mathrm{C}, \mathrm{C}^{10}\right), 131.2\left(\mathrm{CH}, \mathrm{C}^{5}\right), 135.7(\mathrm{C}, \mathrm{C}=\mathrm{C}), 138.0\left(\mathrm{CH}, \mathrm{C}^{7}\right)$, $138.9\left(\mathrm{CH}, \mathrm{C}^{4}\right), 148.9\left(\mathrm{C}, \mathrm{C}^{9}\right), 158.0\left(\mathrm{CH}, \mathrm{C}^{2}\right), 160.5(\mathrm{C}, \mathrm{C}=\mathrm{C}), 160.5$ $(C, C=0), 165.8(C, C=0), 166.1(C, C=0), 172.6(C, C=0)$; two signals $\mathrm{C},(\mathrm{C}=\mathrm{C})$ not detectable.

IR ( $\mathrm{KBr}$ pellets): $v_{\mathrm{C}=\mathrm{O}} 1724,1714,1704 \mathrm{~cm}^{-1}$

Anal. Calc. for $\mathrm{C}_{25} \mathrm{H}_{27} \mathrm{I}_{2} \mathrm{NO}_{8} \mathrm{PdS}$ : C, 34.84; $\mathrm{H}, 3.16$; $\mathrm{N}, 1.63$. Found: C, 35.01; H, 3.07; N, 1.74.

\subsection{Synthesis of complex $2 \mathrm{c}$}

Yellow microcrystals. Yield $89 \%$.

${ }^{1} \mathrm{H} \mathrm{NMR}\left(300 \mathrm{MHz}, \mathrm{CDCl}_{3}, T=298 \mathrm{~K}, \mathrm{ppm}\right) \delta: 2.92\left(\mathrm{~s}, 3 \mathrm{H}, \mathrm{SCH}_{3}\right)$, $3.29\left(\mathrm{~s}, 3 \mathrm{H}\right.$, qui- $\left.\mathrm{CH}_{3}\right), 3.74\left(\mathrm{~s}, 3 \mathrm{H}, \mathrm{OCH}_{3}\right), 3.80\left(\mathrm{~s}, 3 \mathrm{H}, \mathrm{OCH}_{3}\right), 3.83(\mathrm{~s}$, $\left.6 \mathrm{H}, \mathrm{OCH}_{3}\right), 7.43\left(\mathrm{~d}, 1 \mathrm{H}, J=8.4 \mathrm{~Hz}, \mathrm{H}^{3}\right), 7.57(\mathrm{dd}, 1 \mathrm{H}, J=8.1,7.3 \mathrm{~Hz}$, $\left.\mathrm{H}^{6}\right), 7.84\left(\mathrm{~d}, 1 \mathrm{H}, J=8.1 \mathrm{~Hz}, \mathrm{H}^{5}\right), 7.91\left(\mathrm{~d}, 1 \mathrm{H}, J=7.3 \mathrm{~Hz}, \mathrm{H}^{7}\right), 8.16$ $\left(\mathrm{d}, 1 \mathrm{H}, J=8.4 \mathrm{~Hz}, \mathrm{H}^{4}\right)$

${ }^{13} \mathrm{C}\left\{{ }^{1} \mathrm{H}\right\}-\mathrm{NMR}\left(\mathrm{CDCl}_{3}, T=298 \mathrm{~K}, \mathrm{ppm}\right) \delta: 26.3\left(\mathrm{CH} 3, \mathrm{SCH}_{3}\right), 33.7$ $\left(\mathrm{CH} 3\right.$, qui- $\left.\mathrm{CH}_{3}\right), 51.8\left(\mathrm{CH}_{3}, \mathrm{OCH}_{3}\right), 52.2\left(\mathrm{CH}_{3}, \mathrm{OCH}_{3}\right), 53.4\left(\mathrm{CH}_{3}\right.$, $\left.\mathrm{OCH}_{3}\right), 53.4\left(\mathrm{CH}_{3}, \mathrm{OCH}_{3}\right), 100.9(\mathrm{C}, \mathrm{C}=\mathrm{CI}), 125.0(\mathrm{CH}, 3-\mathrm{qui}), 126.8$ (CH, 6-qui), 128.0 (C, 10-qui), $129.7(\mathrm{CH}, 5$-qui), $131.9(\mathrm{CH}, 7-$ qui), $132.3(\mathrm{C}, \mathrm{C}=\mathrm{C}), 132.8$ (C, 8-qui), $138.6(\mathrm{CH}, 4$-qui), $145.0(\mathrm{C}$, 
$\mathrm{C}=\mathrm{C}$ ), 147.8 (C, 9-qui), 154.5 (C, $\mathrm{C}=\mathrm{C}), 159.4(\mathrm{C}, \mathrm{C}=\mathrm{O}), 165.1(\mathrm{C}$, $C=0), 166.1(C, C=0), 167.4(\mathrm{CH}, 2-\mathrm{Pyr}), 171.6(\mathrm{C}, \mathrm{C}=0)$.

IR ( $\mathrm{KBr}$ pellets): $v_{\mathrm{C}=\mathrm{O}} 1725 \mathrm{~cm}^{-1}$.

Anal. Calc. for $\mathrm{C}_{23} \mathrm{H}_{23} \mathrm{I}_{2} \mathrm{NO}_{8} \mathrm{PdS}: \mathrm{C}, 33.13 ; \mathrm{H}, 2.78 ; \mathrm{N}, 1.68$. Found: C, 32.98; H, 2.86; N, 1.57.

\subsection{Synthesis of complex $\mathbf{2 d}$}

Yellow microcrystals. Yield $87 \%$.

${ }^{1} \mathrm{H}$ NMR $\left(300 \mathrm{MHz}, \mathrm{CDCl}_{3}, T=298 \mathrm{~K}, \mathrm{ppm}\right) \delta: 1.37$ (s, 9H, C $\left.\left(\mathrm{CH}_{3}\right)_{3}\right), 3.25\left(\mathrm{~s}, 3 \mathrm{H}\right.$, quinoline- $\left.\mathrm{CH}_{3}\right), 3.53\left(\mathrm{bs}, 3 \mathrm{H}, \mathrm{OCH}_{3}\right), 3.72(\mathrm{~s}$, $\left.6 \mathrm{H}, \mathrm{OCH}_{3}\right), 3.88\left(\mathrm{~s}, 3 \mathrm{H}, \mathrm{OCH}_{3}\right), 7.39\left(\mathrm{~d}, 1 \mathrm{H}, J=8.4 \mathrm{~Hz}, \mathrm{H}^{3}\right), 7.59$ $\left(\mathrm{dd}, 1 \mathrm{H}, J=8.2,7.1 \mathrm{~Hz}, \mathrm{H}^{6}\right), 7.90\left(\mathrm{dd}, 1 \mathrm{H}, J=8.2,1.3 \mathrm{~Hz}, \mathrm{H}^{5}\right), 8.01$ $\left(\mathrm{d}, 1 \mathrm{H}, J=7.1 \mathrm{~Hz}, \mathrm{H}^{7}\right), 8.17\left(\mathrm{~d}, 1 \mathrm{H}, J=8.4 \mathrm{~Hz}, \mathrm{H}^{4}\right)$.

${ }^{13} \mathrm{C}\left\{{ }^{1} \mathrm{H}\right\}$-NMR $\left(\mathrm{CDCl}_{3}, T=298 \mathrm{~K}, \mathrm{ppm}\right) \delta: 29.9\left(\mathrm{CH}_{3}, \mathrm{SC}\left(\mathrm{CH}_{3}\right)_{3}\right)$, $33.6\left(\mathrm{CH}_{3}\right.$, quinoline- $\left.\mathrm{CH}_{3}\right), 51.8\left(\mathrm{CH}_{3}, \mathrm{OCH}_{3}\right), 52.2\left(\mathrm{CH}_{3}, \mathrm{OCH}_{3}\right)$, $53.2\left(\mathrm{CH}_{3}, \mathrm{OCH}_{3}\right), 53.2\left(\mathrm{CH}_{3}, \mathrm{OCH}_{3}\right), 57.7\left(\mathrm{C}, \mathrm{C}\left(\mathrm{CH}_{3}\right)_{3}\right), 103.5(\mathrm{C}$, $\mathrm{C}=\mathrm{CI}), 124.5\left(\mathrm{CH}, \mathrm{C}^{3}\right), 126.3\left(\mathrm{CH}, \mathrm{C}^{6}\right), 127.5\left(\mathrm{C}, \mathrm{C}^{10}\right), 129.3\left(\mathrm{C}, \mathrm{C}^{8}\right)$, $130.7\left(\mathrm{CH}, \mathrm{C}^{5}\right), 133.2(\mathrm{C}, \mathrm{C}=\mathrm{C}), 136.7\left(\mathrm{CH}, \mathrm{C}^{7}\right), 138.7\left(\mathrm{CH}, \mathrm{C}^{4}\right)$, $146.5(C, C=C), 149.2\left(C, C^{9}\right), 154.0(C, C=C), 160.0(C, C=0)$, $165.1(C, C=0), 165.9(C, C=0), 166.7\left(C H, C^{2}\right), 171.8(C, C=0)$.

IR ( $\mathrm{KBr}$ pellets): $v_{\mathrm{C}=\mathrm{O}} 1721 \mathrm{~cm}^{-1}$.

Anal. Calc. for $\mathrm{C}_{26} \mathrm{H}_{29} \mathrm{I}_{2} \mathrm{NO}_{8} \mathrm{PdS}$ : C, 35.66; $\mathrm{H}, 3.34 ; \mathrm{N}, 1.60$. Found: C, 35.53; H, 3.19; N, 1.48 .

\subsection{Synthesis of complex $3 \boldsymbol{a}$}

To $0.089 \mathrm{~g}(0.157 \mathrm{mmol})$ of complex 1a dissolved in $10 \mathrm{ml}$ of anhydrous $\mathrm{CH}_{2} \mathrm{Cl}_{2}, 0.0301 \mathrm{~g}(0.188 \mathrm{mmol})$ of $\mathrm{Br}_{2}$ dissolved in $5 \mathrm{ml}$ of anhydrous $\mathrm{CH}_{2} \mathrm{Cl}_{2}$ was added under inert atmosphere (Ar). The resulting mixture, which instantaneously decolorizes was stirred for $5 \mathrm{~min}$. The solution was concentrated to small volume under vacuum and the title complex was precipitated as yellow solid by addition of diethyl ether. The solid was filtered off on a gooch, washed with diethyl ether and $n$-pentane and dried under vacuum at RT. $0.1124 \mathrm{~g}$ (yield 98\%) of the title complex was obtained.

${ }^{1} \mathrm{H}$ NMR (300 MHz, $\left.\mathrm{CDCl}_{3}, T=298 \mathrm{~K}, \mathrm{ppm}\right) \delta: 3.06\left(\mathrm{~s}, 3 \mathrm{H}, \mathrm{SCH}_{3}\right)$, $3.74\left(\mathrm{~s}, 3 \mathrm{H}, \mathrm{OCH}_{3}\right), 3.75\left(\mathrm{~s}, 3 \mathrm{H}, \mathrm{OCH}_{3}\right), 3.86\left(\mathrm{~s}, 3 \mathrm{H}, \mathrm{OCH}_{3}\right), 3.88(\mathrm{~s}$, $\left.3 \mathrm{H}, \mathrm{OCH}_{3}\right), 7.63\left(\mathrm{dd}, 1 \mathrm{H}, J=8.4,5.1 \mathrm{~Hz}, \mathrm{H}^{3}\right), 7.76(\mathrm{dd}, 1 \mathrm{H}, J=8.1$, $\left.7.3 \mathrm{~Hz}, \mathrm{H}^{6}\right), 8.02\left(\mathrm{~d}, 1 \mathrm{H}, J=8.1,1.2 \mathrm{~Hz}, \mathrm{H}^{5}\right), 8.12(\mathrm{dd}, 1 \mathrm{H}, J=7.3$, $1.2 \mathrm{~Hz}, \mathrm{H}^{7}$ ), $8.43\left(\mathrm{dd}, 1 \mathrm{H}, J=8.4,1.5 \mathrm{~Hz}, \mathrm{H}^{4}\right), 9.95(\mathrm{dd}, 1 \mathrm{H}, J=5.1$, $\left.1.5 \mathrm{~Hz}, \mathrm{H}^{2}\right)$.

${ }^{13} \mathrm{C}\left\{{ }^{1} \mathrm{H}\right\}-\mathrm{NMR}\left(\mathrm{CDCl}_{3}, \mathrm{~T}=298 \mathrm{~K}, \mathrm{ppm}\right) \delta: 28.8\left(\mathrm{CH}_{3}, \mathrm{SCH}_{3}\right), 52.0$ $\left(\mathrm{CH}_{3}, \mathrm{OCH}_{3}\right), 52.2\left(\mathrm{CH}_{3}, \mathrm{OCH}_{3}\right), 53.3\left(\mathrm{CH}_{3}, \mathrm{OCH}_{3}\right), 53.3\left(\mathrm{CH}_{3}\right.$, $\left.\mathrm{OCH}_{3}\right), 123.4\left(\mathrm{CH}, \mathrm{C}^{3}\right), 123.9(\mathrm{C}, \mathrm{C}=\mathrm{CBr}), 128.1\left(\mathrm{CH}, \mathrm{C}^{6}\right), 130.3(\mathrm{C}$, $\left.\mathrm{C}^{10}\right), 130.4(\mathrm{C}, \mathrm{C}=\mathrm{C}), 130.5\left(\mathrm{CH}, \mathrm{C}^{5}\right), 133.0\left(\mathrm{C}, \mathrm{C}^{8}\right), 134.7\left(\mathrm{CH}, \mathrm{C}^{7}\right)$, $139.3\left(\mathrm{CH}, \mathrm{C}^{4}\right), 140.5(\mathrm{C}, \mathrm{C}=\mathrm{C}), 147.1\left(\mathrm{C}, \mathrm{C}^{9}\right), 154.7\left(\mathrm{CH}, \mathrm{C}^{2}\right), 157.2$ (C, $C=C), 160.1$ (C, $C=0$ ), 164.1 ( $C, C=0), 165.7$ (C, $C=0), 172.2$ $(\mathrm{C}, \mathrm{C}=\mathrm{O})$.

IR (KBr pellets): $v_{\mathrm{C}=0} 1734,1720,1706,1695 \mathrm{~cm}^{-1}$.

Anal. Calc. for $\mathrm{C}_{22} \mathrm{H}_{21} \mathrm{Br}_{2} \mathrm{NO}_{8} \mathrm{PdS}$ : C, 36.41; H, 2.92; N, 1.93 . Found: C, 36.59; H, 3.03; N, 1.99 .

The synthesis of the complexes $\mathbf{3 b}$-d was carried out following a procedure similar to that described for complex $\mathbf{3 a}$.

\subsection{Synthesis of complex $\mathbf{3 b}$}

Yellow microcrystals. Yield 93\%.

${ }^{1} \mathrm{H}$ NMR (300 MHz, $\left.\mathrm{CDCl}_{3}, T=298 \mathrm{~K}, \mathrm{ppm}\right) \delta: 1.47(\mathrm{~s}, 9 \mathrm{H}, \mathrm{C}$ $\left.\left(\mathrm{CH}_{3}\right)_{3}\right), 3.68$ (bs, $\left.6 \mathrm{H}, \mathrm{OCH}_{3}\right), 3.73\left(\mathrm{~s}, 3 \mathrm{H}, \mathrm{OCH}_{3}\right), 3.87(\mathrm{~s}, 3 \mathrm{H}$, $\left.\mathrm{OCH}_{3}\right), 7.61\left(\mathrm{dd}, 1 \mathrm{H}, J=8.3,5.0 \mathrm{~Hz}, \mathrm{H}^{3}\right), 7.75(\mathrm{dd}, 1 \mathrm{H}, J=8.1$, $\left.7.3 \mathrm{~Hz}, \mathrm{H}^{6}\right), 8.04-8.08\left(\mathrm{~m}, 2 \mathrm{H}, \mathrm{H}^{5}, \mathrm{H}^{7}\right), 8.42(\mathrm{dd}, 1 \mathrm{H}, J=8.3,1.5 \mathrm{~Hz}$, $\left.\mathrm{H}^{4}\right), 9.88$ (bd, $\left.1 \mathrm{H}, \mathrm{H}^{2}\right)$.

${ }^{13} \mathrm{C}\left\{{ }^{1} \mathrm{H}\right\}-\mathrm{NMR}\left(\mathrm{CDCl}_{3}, T=298 \mathrm{~K}, \mathrm{ppm}\right) \delta: 30.2\left(\mathrm{CH}_{3}, \mathrm{SC}\left(\mathrm{CH}_{3}\right)_{3}\right)$, $51.7\left(\mathrm{CH}_{3}, \mathrm{OCH}_{3}\right), 52.1\left(\mathrm{CH}_{3}, \mathrm{OCH}_{3}\right), 53.1\left(\mathrm{CH}_{3}, \mathrm{OCH}_{3}\right), 53.3\left(\mathrm{CH}_{3}\right.$, $\left.\mathrm{OCH}_{3}\right), 59.2\left(\mathrm{C}, \mathrm{C}\left(\mathrm{CH}_{3}\right)_{3}\right), 123.1\left(\mathrm{CH}, \mathrm{C}^{3}\right), 124.0(\mathrm{C}, \mathrm{C}=\mathrm{CBr}), 127.2$
$\left(\mathrm{CH}, \mathrm{C}^{6}\right), 129.2\left(\mathrm{C}, \mathrm{C}^{8}\right), 129.8\left(\mathrm{C}, \mathrm{C}^{10}\right), 130.9\left(\mathrm{CH}, \mathrm{C}^{5}\right), 133.2(\mathrm{C}$, $\mathrm{C}=\mathrm{C}), 137.7\left(\mathrm{CH}, \mathrm{C}^{7}\right), 139.1\left(\mathrm{CH}, \mathrm{C}^{4}\right), 148.8\left(\mathrm{C}, \mathrm{C}^{9}\right), 154.9\left(\mathrm{CH}, \mathrm{C}^{2}\right)$, 155.0 (C, $C=C), 161.2(C, C=0), 161.2(C, C=0), 164.4(C, C=0)$, $172.3(\mathrm{C}, \mathrm{C}=\mathrm{O})$; one signal $\mathrm{C},(\mathrm{C}=\mathrm{C})$ not detectable.

IR ( $\mathrm{KBr}$ pellets): $v_{\mathrm{C}=\mathrm{O}} 1732,1717,1704 \mathrm{~cm}^{-1}$.

Anal. Calc. for $\mathrm{C}_{25} \mathrm{H}_{27} \mathrm{Br}_{2} \mathrm{NO}_{8} \mathrm{PdS}$ : C, 39.11; $\mathrm{H}, 3.54 ; \mathrm{N}, 1.82$. Found: C, 38.98; $\mathrm{H}, 3.67$; N, 1.71 .

\subsection{Synthesis of complex $3 c$}

Yellow microcrystals. Yield $88 \%$.

${ }^{1} \mathrm{H}$ NMR (300 MHz, $\left.\mathrm{CDCl}_{3}, T=298 \mathrm{~K}, \mathrm{ppm}\right) \delta: 2.89\left(\mathrm{~s}, 3 \mathrm{H}, \mathrm{SCH}_{3}\right)$, $3.26\left(\mathrm{~s}, 3 \mathrm{H}\right.$, qui- $\left.-\mathrm{CH}_{3}\right), 3.74\left(\mathrm{~s}, 3 \mathrm{H}, \mathrm{OCH}_{3}\right), 3.80\left(\mathrm{~s}, 3 \mathrm{H}, \mathrm{OCH}_{3}\right), 3.85$ (bs, 6H, $\left.\mathrm{OCH}_{3}\right), 7.43\left(\mathrm{~d}, 1 \mathrm{H}, J=8.4 \mathrm{~Hz}, \mathrm{H}_{3}\right), 7.58(\mathrm{dd}, 1 \mathrm{H}$, $\left.J=8.1,7.2 \mathrm{~Hz}, \mathrm{H}^{6}\right), 7.87\left(\mathrm{~d}, 1 \mathrm{H}, J=8.1 \mathrm{~Hz}, \mathrm{H}^{5}\right), 7.92(\mathrm{~d}, 1 \mathrm{H}$, $\left.J=7.2 \mathrm{~Hz}, \mathrm{H}^{7}\right), 8.18\left(\mathrm{~d}, 1 \mathrm{H}, J=8.4 \mathrm{~Hz}, \mathrm{H}^{4}\right)$

${ }^{13} \mathrm{C}\left\{{ }^{1} \mathrm{H}\right\}-\mathrm{NMR}\left(\mathrm{CDCl}_{3}, \mathrm{~T}=298 \mathrm{~K}, \mathrm{ppm}\right) \delta: 26.4\left(\mathrm{CH}_{3}, \mathrm{SCH}_{3}\right), 30.2$ $\left(\mathrm{CH}_{3}\right.$, qui- $\left.\mathrm{CH}_{3}\right), 52.0\left(\mathrm{CH}_{3}, \mathrm{OCH}_{3}\right), 52.2\left(\mathrm{CH}_{3}, \mathrm{OCH}_{3}\right), 53.4\left(\mathrm{CH}_{3}\right.$, $\left.\mathrm{OCH}_{3}\right), 53.4\left(\mathrm{CH}_{3}, \mathrm{OCH}_{3}\right), 125.4(\mathrm{CH}, 3-q u i), 126.8(\mathrm{CH}, 6-q u i)$, 128.1 (C, 10-qui), 129.6 (C, $\mathrm{C}=\mathrm{CBr}$ ), 130.0 ( $\mathrm{CH}, 5$-qui), 132.3 (C, $\mathrm{C}=\mathrm{C}$ ), 132.4 ( $\mathrm{CH}, 7$-qui), 132.5 (C, 8-qui), 138.5 ( $\mathrm{CH}, 4$-qui), 147.7 (C, 9-qui), 160.0 (C, $C=0$ ), 164.2 (C, $C=0), 165.9$ (C, $C=0), 167.5$ ( $\mathrm{CH}, 2-\mathrm{Pyr}), 171.2(\mathrm{C}, \mathrm{C}=\mathrm{O}) .(2$ signals $\mathrm{C}=\mathrm{C}$ cannot be detected $)$.

IR ( $\mathrm{KBr}$ pellets): $v_{\mathrm{C}=\mathrm{O}} 1724 \mathrm{~cm}^{-1}$.

Anal. Calc. for $\mathrm{C}_{23} \mathrm{H}_{23} \mathrm{Br}_{2} \mathrm{NO}_{8} \mathrm{PdS}$ : C, 37.34; $\mathrm{H}, 3.13 ; \mathrm{N}, 1.89$. Found: C, 37.29; $\mathrm{H}, 3.21$; N, 1.77 .

\subsection{Synthesis of complex $3 \boldsymbol{d}$}

Yellow microcrystals. Yield $90 \%$.

${ }^{1} \mathrm{H}$ NMR (300 MHz, $\left.\mathrm{CDCl}_{3}, T=298 \mathrm{~K}, \mathrm{ppm}\right) \delta: 1.37$ (s, 9H, C $\left.\left(\mathrm{CH}_{3}\right)_{3}\right), 3.22\left(\mathrm{~s}, 3 \mathrm{H}\right.$, quinoline- $\left.\mathrm{CH}_{3}\right), 3.55\left(\mathrm{~s}, 3 \mathrm{H}, \mathrm{OCH}_{3}\right), 3.71(\mathrm{~s}$, $\left.3 \mathrm{H}, \mathrm{OCH}_{3}\right), 3.72\left(\mathrm{~s}, 3 \mathrm{H}, \mathrm{OCH}_{3}\right), 3.90\left(\mathrm{~s}, 3 \mathrm{H}, \mathrm{OCH}_{3}\right), 7.39(\mathrm{~d}, 1 \mathrm{H}$, $\left.J=8.4 \mathrm{~Hz}, \mathrm{H}^{3}\right), 7.61\left(\mathrm{dd}, 1 \mathrm{H}, J=8.1,7.2 \mathrm{~Hz}, \mathrm{H}^{6}\right), 7.94(\mathrm{~d}, 1 \mathrm{H}$, $\left.J=8.1,1.3 \mathrm{~Hz}, \mathrm{H}^{5}\right), 7.98\left(\mathrm{~d}, 1 \mathrm{H}, J=7.2 \mathrm{~Hz}, \mathrm{H}^{7}\right), 8.19(\mathrm{~d}, 1 \mathrm{H}$, $\left.J=8.4 \mathrm{~Hz}, \mathrm{H}^{4}\right)$.

${ }^{13} \mathrm{C}\left\{{ }^{1} \mathrm{H}\right\}-\mathrm{NMR}\left(\mathrm{CDCl}_{3}, T=298 \mathrm{~K}, \mathrm{ppm}\right) \delta: 29.9\left(\mathrm{CH}_{3}, \mathrm{SC}\left(\mathrm{CH}_{3}\right)_{3}\right)$, $30.2\left(\mathrm{CH}_{3}\right.$, quinoline- $\left.\mathrm{CH}_{3}\right), 52.0\left(\mathrm{CH}_{3}, \mathrm{OCH}_{3}\right), 52.1\left(\mathrm{CH}_{3}, \mathrm{OCH}_{3}\right)$, $53.2\left(\mathrm{CH}_{3}, \mathrm{OCH}_{3}\right), 53.2\left(\mathrm{CH}_{3}, \mathrm{OCH}_{3}\right), 57.6\left(\mathrm{C}, \mathrm{C}\left(\mathrm{CH}_{3}\right)_{3}\right), 123.7(\mathrm{C}$, $\mathrm{C}=\mathrm{CBr}), 124.9\left(\mathrm{CH}, \mathrm{C}^{3}\right), 126.3\left(\mathrm{CH}, \mathrm{C}^{6}\right), 127.6\left(\mathrm{C}, \mathrm{C}^{10}\right), 129.2(\mathrm{C}$, $\left.\mathrm{C}^{8}\right), 130.9\left(\mathrm{CH}, \mathrm{C}^{5}\right), 131.3(\mathrm{C}, \mathrm{C}=\mathrm{C}), 136.7\left(\mathrm{CH}, \mathrm{C}^{7}\right), 138.5\left(\mathrm{CH}, \mathrm{C}^{4}\right)$, $140.5(C, C=C), 149.0\left(C, C^{9}\right), 155.0(C, C=C), 160.6(C, C=0)$, $164.3(C, C=0), 165.8(C, C=0), 166.7\left(C H, C^{2}\right), 171.5(C, C=0)$.

IR ( $\mathrm{KBr}$ pellets): $v_{\mathrm{C}=\mathrm{O}} 1718 \mathrm{~cm}^{-1}$.

Anal. Calc. for $\mathrm{C}_{26} \mathrm{H}_{29} \mathrm{Br}_{2} \mathrm{NO}_{8} \mathrm{PdS}$ : C, 39.94; H, 3.74; N, 1.79 . Found: C, 40.06; H, 3.88; N, 1.65 .

\subsection{Synthesis of complex $\mathbf{4 a}$}

To $0.0913 \mathrm{~g}(0.161 \mathrm{mmol})$ of complex 1a dissolved in $10 \mathrm{ml}$ of anhydrous $\mathrm{CH}_{2} \mathrm{Cl}_{2}, 0.0288 \mathrm{~g}(0.177 \mathrm{mmol})$ of $\mathrm{ICl}$ dissolved in $5 \mathrm{ml}$ of anhydrous $\mathrm{CH}_{2} \mathrm{Cl}_{2}$, was added under inert atmosphere (Ar). The resulting mixture which instantaneously turned from dark red to yellow, was stirred for $5 \mathrm{~min}$. The solution was concentrated to small volume under vacuum and the title complex was precipitated as yellow solid by addition of diethyl ether. The solid was filtered off on a gooch, washed with diethyl ether and $n$-pentane and dried under vacuum at RT. $0.1128 \mathrm{~g}$ (yield 96\%) of the title complex was obtained.

${ }^{1} \mathrm{H}$ NMR (300 MHz, $\left.\mathrm{CDCl}_{3}, T=298 \mathrm{~K}, \mathrm{ppm}\right) \delta: 3.08\left(\mathrm{~s}, 3 \mathrm{H}, \mathrm{SCH}_{3}\right)$, $3.74\left(\mathrm{~s}, 3 \mathrm{H}, \mathrm{OCH}_{3}\right), 3.75\left(\mathrm{~s}, 3 \mathrm{H}, \mathrm{OCH}_{3}\right), 3.85\left(\mathrm{~s}, 3 \mathrm{H}, \mathrm{OCH}_{3}\right), 3.90(\mathrm{~s}$, $\left.3 \mathrm{H}, \mathrm{OCH}_{3}\right), 7.65\left(\mathrm{dd}, 1 \mathrm{H}, J=8.3,5.0 \mathrm{~Hz}, \mathrm{H}^{3}\right), 7.76(\mathrm{dd}, 1 \mathrm{H}, J=8.2$, $\left.7.4 \mathrm{~Hz}, \mathrm{H}^{6}\right), 8.03\left(\mathrm{~d}, 1 \mathrm{H}, J=8.2,1.1 \mathrm{~Hz}, \mathrm{H}^{5}\right), 8.13(\mathrm{dd}, 1 \mathrm{H}, J=7.4$, $1.1 \mathrm{~Hz}, \mathrm{H}^{7}$ ), $8.44\left(\mathrm{dd}, 1 \mathrm{H}, J=8.3,1.5 \mathrm{~Hz}, \mathrm{H}^{4}\right), 9.74(\mathrm{dd}, 1 \mathrm{H}, J=5.0$, $\left.1.5 \mathrm{~Hz}, \mathrm{H}^{2}\right)$. 
${ }^{13} \mathrm{C}\left\{{ }^{1} \mathrm{H}\right\}-\mathrm{NMR}\left(\mathrm{CDCl}_{3}, T=298 \mathrm{~K}, \mathrm{ppm}\right) \delta: 29.0\left(\mathrm{CH}_{3}, \mathrm{SCH}_{3}\right), 52.1$ $\left(\mathrm{CH}_{3}, \mathrm{OCH}_{3}\right), 52.2\left(\mathrm{CH}_{3}, \mathrm{OCH}_{3}\right), 53.2\left(\mathrm{CH}_{3}, \mathrm{OCH}_{3}\right), 53.3\left(\mathrm{CH}_{3}\right.$, $\left.\mathrm{OCH}_{3}\right), 103.9(\mathrm{C}, \mathrm{C}=\mathrm{CI}), 123.1\left(\mathrm{CH}, \mathrm{C}^{3}\right), 128.1\left(\mathrm{CH}, \mathrm{C}^{6}\right), 130.2(\mathrm{C}$, $\left.\mathrm{C}^{10}\right), 130.5\left(\mathrm{CH}, \mathrm{C}^{5}\right), 133.1\left(\mathrm{C}, \mathrm{C}^{8}\right), 133.3(\mathrm{C}, \mathrm{C}=\mathrm{C}), 134.7\left(\mathrm{CH}, \mathrm{C}^{7}\right)$, 139.4 (CH, $\left.\mathrm{C}^{4}\right), 145.0(\mathrm{C}, \mathrm{C}=\mathrm{C}), 147.0\left(\mathrm{C}, \mathrm{C}^{9}\right), 152.9\left(\mathrm{CH}, \mathrm{C}^{2}\right), 158.8$ (C, $C=C), 159.8(C, C=0), 165.1(C, C=0), 166.1(C, C=0), 172.1$ (C, $\mathrm{C}=\mathrm{O})$.

IR ( $\mathrm{KBr}$ pellets): $v_{\mathrm{C}=\mathrm{O}} 1716 \mathrm{~cm}^{-1}$.

Anal. Calc. for $\mathrm{C}_{22} \mathrm{H}_{21} \mathrm{ClINO}_{8} \mathrm{PdS}$ : C, 36.28; $\mathrm{H}, 2.91 ; \mathrm{N}, 1.92$. Found: C, 36.33; $\mathrm{H}, 2.87 ; \mathrm{N}, 1.78$.

The synthesis of the complexes $\mathbf{4 b} \mathbf{b}-\mathbf{d}$ was carried out following a procedure similar to that described for complex $\mathbf{4 a}$.

\subsection{Synthesis of complex $\mathbf{4 b}$}

Yellow microcrystals. Yield 99\%.

${ }^{1} \mathrm{H}$ NMR $\left(300 \mathrm{MHz}, \mathrm{CDCl}_{3}, T=298 \mathrm{~K}, \mathrm{ppm}\right) \delta: 1.47(\mathrm{~s}, 9 \mathrm{H}, \mathrm{C}$ $\left.\left(\mathrm{CH}_{3}\right)_{3}\right), 3.65$ (bs, $\left.6 \mathrm{H}, \mathrm{OCH}_{3}\right), 3.73\left(\mathrm{~s}, 3 \mathrm{H}, \mathrm{OCH}_{3}\right), 3.89(\mathrm{~s}, 3 \mathrm{H}$, $\left.\mathrm{OCH}_{3}\right), 7.63\left(\mathrm{dd}, 1 \mathrm{H}, J=8.2,5.0 \mathrm{~Hz}, \mathrm{H}^{3}\right), 7.75(\mathrm{dd}, 1 \mathrm{H}, J=8.2$, $\left.7.3 \mathrm{~Hz}, \mathrm{H}^{6}\right), 8.05\left(\mathrm{~d}, 1 \mathrm{H}, J=8.1 \mathrm{~Hz}, \mathrm{H}^{5}\right), 8.08\left(\mathrm{bs}, 1 \mathrm{H}, \mathrm{H}^{7}\right), 8.43(\mathrm{dd}$, $\left.1 \mathrm{H}, J=8.3,1.5 \mathrm{~Hz}, \mathrm{H}^{4}\right), 9.64$ (bs, $1 \mathrm{H}, \mathrm{H}^{2}$ ).

${ }^{13} \mathrm{C}\left\{{ }^{1} \mathrm{H}\right\}-\mathrm{NMR}\left(\mathrm{CDCl}_{3}, T=298 \mathrm{~K}, \mathrm{ppm}\right) \delta: 30.1\left(\mathrm{CH}_{3}, \mathrm{SC}\left(\mathrm{CH}_{3}\right)_{3}\right)$, $51.7\left(\mathrm{CH}_{3}, \mathrm{OCH}_{3}\right), 52.1\left(\mathrm{CH}_{3}, \mathrm{OCH}_{3}\right), 53.1\left(\mathrm{CH}_{3}, \mathrm{OCH}_{3}\right), 53.1\left(\mathrm{CH}_{3}\right.$, $\left.\mathrm{OCH}_{3}\right), 59.0\left(\mathrm{C}, \mathrm{C}\left(\mathrm{CH}_{3}\right)_{3}\right), 103.7(\mathrm{C}, \mathrm{C}=\mathrm{CI}), 122.9\left(\mathrm{CH}, \mathrm{C}^{3}\right), 127.3$ $\left(\mathrm{CH}, \mathrm{C}^{6}\right), 129.4\left(\mathrm{C}, \mathrm{C}^{8}\right), 129.8\left(\mathrm{C}, \mathrm{C}^{10}\right), 131.2\left(\mathrm{CH}, \mathrm{C}^{5}\right), 135.5(\mathrm{C}$, $\mathrm{C}=\mathrm{C}), 137.4\left(\mathrm{CH}, \mathrm{C}^{7}\right), 139.2\left(\mathrm{CH}, \mathrm{C}^{4}\right), 148.7\left(\mathrm{C}, \mathrm{C}^{9}\right), 153.1\left(\mathrm{CH}, \mathrm{C}^{2}\right)$, 157.8 (C, $C=C), 160.7$ (C, $C=0), 166.0$ (C, $C=0), 166.2(C, C=0)$, $172.1(C, C=0)$; one signal $C,(C=C)$ not detectable.

IR ( $\mathrm{KBr}$ pellets): $v_{\mathrm{C}=\mathrm{O}} 1718 \mathrm{~cm}^{-1}$.

Anal. Calc. for $\mathrm{C}_{25} \mathrm{H}_{27} \mathrm{ClINO}_{8} \mathrm{PdS}$ : C, 38.98; $\mathrm{H}, 3.53 ; \mathrm{N}, 1.82$. Found: C, 39.13; H, 3.61; N, 1.79 .

\subsection{Synthesis of complex $\mathbf{4 c}$}

Yellow microcrystals. Yield 92\%.

${ }^{1} \mathrm{H}$ NMR ( $\left.300 \mathrm{MHz}, \mathrm{CDCl}_{3}, T=298 \mathrm{~K}, \mathrm{ppm}\right) \delta: 2.91$ (bs, 3H, $\mathrm{SCH}_{3}$ ), $3.23\left(\mathrm{~s}, 3 \mathrm{H}\right.$, qui- $\left.\mathrm{CH}_{3}\right), 3.77\left(\mathrm{~s}, 3 \mathrm{H}, \mathrm{OCH}_{3}\right), 3.84\left(\mathrm{~s}, 3 \mathrm{H}, \mathrm{OCH}_{3}\right), 3.85(\mathrm{~s}$, $\left.3 \mathrm{H}, \mathrm{OCH}_{3}\right), 3.87\left(\mathrm{~s}, 3 \mathrm{H}, \mathrm{OCH}_{3}\right), 7.42\left(\mathrm{~d}, 1 \mathrm{H}, J=8.5 \mathrm{~Hz}, \mathrm{H}^{3}\right), 7.59$ (dd, $\left.1 \mathrm{H}, J=8.1,7.1 \mathrm{~Hz}, \mathrm{H}^{6}\right), 7.89\left(\mathrm{~d}, 1 \mathrm{H}, J=8.1 \mathrm{~Hz}, \mathrm{H}^{5}\right), 7.94(\mathrm{~d}, 1 \mathrm{H}$, $\left.J=7.1 \mathrm{~Hz}, \mathrm{H}^{7}\right), 8.19\left(\mathrm{~d}, 1 \mathrm{H}, J=8.5 \mathrm{~Hz}, \mathrm{H}^{4}\right)$.

${ }^{13} \mathrm{C}\left\{{ }^{1} \mathrm{H}\right\}-\mathrm{NMR}\left(\mathrm{CDCl}_{3}, T=298 \mathrm{~K}, \mathrm{ppm}\right) \delta: 27.3\left(\mathrm{bs}, \mathrm{CH}_{3}, \mathrm{SCH}_{3}\right)$, $28.3\left(\mathrm{CH}_{3}\right.$, qui- $\left.\mathrm{CH}_{3}\right), 52.1\left(\mathrm{CH}_{3}, \mathrm{OCH}_{3}\right), 52.2\left(\mathrm{CH}_{3}, \mathrm{OCH}_{3}\right), 53.2$ $\left(\mathrm{CH}_{3}, \mathrm{OCH}_{3}\right), 53.3\left(\mathrm{CH}_{3}, \mathrm{OCH}_{3}\right), 101.2(\mathrm{C}, \mathrm{C}=\mathrm{CI}), 125.7(\mathrm{CH}, 3-q u i)$, 126.8 (CH, 6-qui), 128.1 (C, 10-qui), $130.3(\mathrm{CH}, 5$-qui), $132.3(\mathrm{CH}$, 7-qui), 132.4 (C, 8-qui), 138.6 ( $\mathrm{CH}, 4$-qui), 147.6 (C, 9-qui), 159.6 (C, $C=0), 163.4(C, C=0), 166.2$ (C, $C=0), 167.6$ (CH, 2-Pyr), $171.1(C, C=0),(3 C=C$ signals were not detectable $)$.

IR ( $\mathrm{KBr}$ pellets): $v_{\mathrm{C}=\mathrm{O}} 1721 \mathrm{~cm}^{-1}$.

Anal. Calc. for $\mathrm{C}_{23} \mathrm{H}_{23} \mathrm{ClINO}_{8} \mathrm{PdS}$ : C, 37.22; H, 3.12; N, 1.89 . Found: C, 37.39; H, 3.11; N, 1.75 .

\subsection{Synthesis of complex $\mathbf{4 d}$}

Yellow microcrystals. Yield 95\%.

${ }^{1} \mathrm{H}$ NMR (300 MHz, $\left.\mathrm{CDCl}_{3}, T=298 \mathrm{~K}, \mathrm{ppm}\right) \delta: 1.38$ (s, 9H, C $\left.\left(\mathrm{CH}_{3}\right)_{3}\right), 3.19\left(\mathrm{~s}, 3 \mathrm{H}\right.$, quinoline- $\left.\mathrm{CH}_{3}\right), 3.51\left(\mathrm{bs}, 3 \mathrm{H}, \mathrm{OCH}_{3}\right), 3.69(\mathrm{~s}$, $\left.3 \mathrm{H}, \mathrm{OCH}_{3}\right)$ ), $3.72\left(\mathrm{~s}, 3 \mathrm{H}, \mathrm{OCH}_{3}\right), 3.92\left(\mathrm{~s}, 3 \mathrm{H}, \mathrm{OCH}_{3}\right), 7.38(\mathrm{~d}, 1 \mathrm{H}$, $\left.J=8.4 \mathrm{~Hz}, \mathrm{H}^{3}\right), 7.62\left(\mathrm{dd}, 1 \mathrm{H}, J=8.1,7.1 \mathrm{~Hz}, \mathrm{H}^{6}\right), 7.94(\mathrm{~d}, 1 \mathrm{H}$, $\left.J=8.1 \mathrm{~Hz}, \mathrm{H}^{5}\right), 8.01\left(\mathrm{bd}, 1 \mathrm{H}, \mathrm{H}^{7}\right), 8.19\left(\mathrm{~d}, 1 \mathrm{H}, J=8.4 \mathrm{~Hz}, \mathrm{H}^{4}\right)$.

${ }^{13} \mathrm{C}\left\{{ }^{1} \mathrm{H}\right\}-\mathrm{NMR}\left(\mathrm{CDCl}_{3}, T=298 \mathrm{~K}, \mathrm{ppm}\right) \delta: 29.9\left(\mathrm{CH}_{3}, \mathrm{SC}\left(\mathrm{CH}_{3}\right)_{3}\right)$, $28.3\left(\mathrm{CH}_{3}\right.$, quinoline- $\left.\mathrm{CH}_{3}\right), 52.1\left(\mathrm{CH}_{3}, \mathrm{OCH}_{3}\right), 52.2\left(\mathrm{CH}_{3}, \mathrm{OCH}_{3}\right)$, $53.0\left(\mathrm{CH}_{3}, \mathrm{OCH}_{3}\right), 53.2\left(\mathrm{CH}_{3}, \mathrm{OCH}_{3}\right), 57.5\left(\mathrm{C}, \mathrm{C}\left(\mathrm{CH}_{3}\right)_{3}\right), 103.7(\mathrm{C}$, $\mathrm{C}=\mathrm{CI}), 125.1\left(\mathrm{CH}, \mathrm{C}^{3}\right), 126.3\left(\mathrm{CH}, \mathrm{C}^{6}\right), 127.5\left(\mathrm{C}, \mathrm{C}^{10}\right), 129.1\left(\mathrm{C}, \mathrm{C}^{8}\right)$, $130.9\left(\mathrm{CH}, \mathrm{C}^{5}\right), 133.7(\mathrm{C}, \mathrm{C}=\mathrm{C}), 136.7\left(\mathrm{CH}, \mathrm{C}^{7}\right), 138.5\left(\mathrm{CH}, \mathrm{C}^{4}\right)$, $145.7(\mathrm{C}, \mathrm{C}=\mathrm{C}), 149.0\left(\mathrm{C}, \mathrm{C}^{9}\right), 156.5(\mathrm{C}, \mathrm{C}=\mathrm{C}), 160.2(\mathrm{C}, \mathrm{C}=\mathrm{O})$, $165.5(C, C=0), 166.0(C, C=0), 166.6\left(C H, C^{2}\right), 171.4(C, C=0)$.
IR (KBr pellets): $v_{\mathrm{C}=\mathrm{O}} 1711 \mathrm{~cm}^{-1}$.

Anal. Calc. for $\mathrm{C}_{26} \mathrm{H}_{29} \mathrm{ClINO}_{8} \mathrm{PdS}$ : C, 39.81; H, 3.73; N, 1.79 . Found: C, 39.97; H, 3.62; N, 1.84.

\subsection{Synthesis of complex $\mathbf{5 a}$}

To $0.0900 \mathrm{~g}$ ( $0.159 \mathrm{mmol})$ of complex 1a dissolved in $10 \mathrm{ml}$ of anhydrous $\mathrm{CH}_{2} \mathrm{Cl}_{2}, 0.0393 \mathrm{~g}(0.190 \mathrm{mmol})$ of $\mathrm{IBr}$ dissolved in $5 \mathrm{ml}$ of anhydrous $\mathrm{CH}_{2} \mathrm{Cl}_{2}$, was added under inert atmosphere (Ar). The resulting mixture which instantaneously turned from red to yellow, was stirred for $5 \mathrm{~min}$. The solution was concentrated to small volume under vacuum and The title complex was precipitated as yellow solid by addition of diethyl ether. The solid was filtered off on a gooch, washed with diethyl ether and $n$-pentane and dried under vacuum at RT. $0.1104 \mathrm{~g}$ (yield 90\%) of the title complex was obtained.

${ }^{1} \mathrm{H}$ NMR $\left(300 \mathrm{MHz}, \mathrm{CDCl}_{3}, T=298 \mathrm{~K}, \mathrm{ppm}\right) \delta: 3.09\left(\mathrm{~s}, 3 \mathrm{H}, \mathrm{SCH}_{3}\right)$, $3.74\left(\mathrm{~s}, 3 \mathrm{H}, \mathrm{OCH}_{3}\right), 3.75\left(\mathrm{~s}, 3 \mathrm{H}, \mathrm{OCH}_{3}\right), 3.85\left(\mathrm{~s}, 3 \mathrm{H}, \mathrm{OCH}_{3}\right), 3.89(\mathrm{~s}$, $\left.3 \mathrm{H}, \mathrm{OCH}_{3}\right), 7.63\left(\mathrm{dd}, 1 \mathrm{H}, J=8.3,5.0 \mathrm{~Hz}, \mathrm{H}^{3}\right), 7.76(\mathrm{dd}, 1 \mathrm{H}, J=8.2$, $\left.7.4 \mathrm{~Hz}, \mathrm{H}^{6}\right), 8.02\left(\mathrm{dd}, 1 \mathrm{H}, J=8.2,1.1 \mathrm{~Hz}, \mathrm{H}^{5}\right), 8.13(\mathrm{dd}, 1 \mathrm{H}, J=7.4$, $\left.1.1 \mathrm{~Hz}, \mathrm{H}^{7}\right), 8.43\left(\mathrm{dd}, 1 \mathrm{H}, J=8.3,1.6 \mathrm{~Hz}, \mathrm{H}^{4}\right), 9.95(\mathrm{dd}, 1 \mathrm{H}, J=5.0$, $\left.1.6 \mathrm{~Hz}, \mathrm{H}^{2}\right)$.

${ }^{13} \mathrm{C}\left\{{ }^{1} \mathrm{H}\right\}-\mathrm{NMR}\left(\mathrm{CDCl}_{3}, T=298 \mathrm{~K}, \mathrm{ppm}\right) \delta: 29.1\left(\mathrm{CH}_{3}, \mathrm{SCH}_{3}\right), 52.0$ $\left(\mathrm{CH}_{3}, \mathrm{OCH}_{3}\right), 52.2\left(\mathrm{CH}_{3}, \mathrm{OCH}_{3}\right), 53.2\left(\mathrm{CH}_{3}, \mathrm{OCH}_{3}\right), 53.4\left(\mathrm{CH}_{3}\right.$, $\left.\mathrm{OCH}_{3}\right), 59.2\left(\mathrm{C}, \mathrm{C}\left(\mathrm{CH}_{3}\right)_{3}\right), 103.7(\mathrm{C}, \mathrm{C}=\mathrm{CI}), 123.3\left(\mathrm{CH}, \mathrm{C}^{3}\right), 128.1$ $\left(\mathrm{CH}, \mathrm{C}^{6}\right), 130.2\left(\mathrm{C}, \mathrm{C}^{10}\right), 130.5\left(\mathrm{CH}, \mathrm{C}^{5}\right), 133.1\left(\mathrm{C}, \mathrm{C}^{8}\right), 133.3(\mathrm{C}$, $\mathrm{C}=\mathrm{C}), 134.8\left(\mathrm{CH}, \mathrm{C}^{7}\right), 139.1(\mathrm{C}, \mathrm{C}=\mathrm{C}), 139.3\left(\mathrm{CH}, \mathrm{C}^{4}\right), 147.1\left(\mathrm{C}, \mathrm{C}^{9}\right)$, $154.7\left(\mathrm{CH}, \mathrm{C}^{2}\right), 157.2(\mathrm{C}, \mathrm{C}=\mathrm{C}), 159.7(\mathrm{C}, \mathrm{C}=\mathrm{O}), 165.1(\mathrm{C}, \mathrm{C}=\mathrm{O})$, $166.0(\mathrm{C}, \mathrm{C}=\mathrm{O}), 172.2(\mathrm{C}, \mathrm{C}=\mathrm{O})$.

IR ( $\mathrm{KBr}$ pellets): $v_{\mathrm{C}=\mathrm{O}} 1716 \mathrm{~cm}^{-1}$.

Anal. Calc. for $\mathrm{C}_{22} \mathrm{H}_{21} \mathrm{BrINO}_{8} \mathrm{PdS}$ : C, 34.20; $\mathrm{H}, 2.74 ; \mathrm{N}, 1.81$. Found: C, 34.35; H, 2.79; N, 1.74.

The synthesis of the complexes $\mathbf{5 b} \mathbf{b} \mathbf{d}$ was carried out following a procedure similar to that described for complex $\mathbf{5 a}$.

\subsection{Synthesis of complex $\mathbf{5 b}$}

Yellow microcrystals. Yield $92 \%$.

${ }^{1} \mathrm{H}$ NMR (300 MHz, $\left.\mathrm{CDCl}_{3}, T=298 \mathrm{~K}, \mathrm{ppm}\right) \delta: 1.47(\mathrm{~s}, 9 \mathrm{H}, \mathrm{C}$ $\left.\left(\mathrm{CH}_{3}\right)_{3}\right), 3.65$ (bs, 6H, OCH $\left.)_{3}\right) 3.73\left(\mathrm{~s}, 3 \mathrm{H}, \mathrm{OCH}_{3}\right), 3.87(\mathrm{~s}, 3 \mathrm{H}$, $\left.\mathrm{OCH}_{3}\right), 7.60\left(\mathrm{dd}, 1 \mathrm{H}, J=8.3,5.0 \mathrm{~Hz}, \mathrm{H}^{3}\right), 7.74(\mathrm{dd}, 1 \mathrm{H}, J=8.2$, $\left.7.3 \mathrm{~Hz}, \mathrm{H}^{6}\right), 8.05\left(\mathrm{~d}, 1 \mathrm{H}, J=8.2 \mathrm{~Hz}, \mathrm{H}^{5}\right), 8.09\left(\mathrm{bd}, 1 \mathrm{H}, \mathrm{H}^{7}\right), 8.41(\mathrm{dd}$, $\left.1 \mathrm{H}, J=8.3,1.5 \mathrm{~Hz}, \mathrm{H}^{4}\right), 9.83$ (bs, $1 \mathrm{H}, \mathrm{H}^{2}$ ).

${ }^{13} \mathrm{C}\left\{{ }^{1} \mathrm{H}\right\}-\mathrm{NMR}\left(\mathrm{CDCl}_{3}, T=298 \mathrm{~K}, \mathrm{ppm}\right) \delta: 30.2\left(\mathrm{CH}_{3}, \mathrm{SC}\left(\mathrm{CH}_{3}\right)_{3}\right)$, $51.6\left(\mathrm{CH}_{3}, \mathrm{OCH}_{3}\right), 52.2\left(\mathrm{CH}_{3}, \mathrm{OCH}_{3}\right), 53.1\left(\mathrm{CH}_{3}, \mathrm{OCH}_{3}\right), 53.1\left(\mathrm{CH}_{3}\right.$, $\left.\mathrm{OCH}_{3}\right), 59.2\left(\mathrm{C}, \mathrm{C}\left(\mathrm{CH}_{3}\right)_{3}\right), 103.7(\mathrm{C}, \mathrm{C}=\mathrm{CI}), 123.0\left(\mathrm{CH}, \mathrm{C}^{3}\right), 127.2$ $\left(\mathrm{CH}, \mathrm{C}^{6}\right), 129.3\left(\mathrm{C}, \mathrm{C}^{8}\right), 129.8\left(\mathrm{C}, \mathrm{C}^{10}\right), 130.3\left(\mathrm{CH}, \mathrm{C}^{5}\right), 135.7(\mathrm{C}$, $\mathrm{C}=\mathrm{C}), 137.6\left(\mathrm{CH}, \mathrm{C}^{7}\right), 139.1(\mathrm{C}, \mathrm{C}=\mathrm{C}), 139.1\left(\mathrm{CH}, \mathrm{C}^{4}\right), 148.8\left(\mathrm{C}, \mathrm{C}^{9}\right)$, $154.9\left(\mathrm{CH}, \mathrm{C}^{2}\right), 155.6(\mathrm{C}, \mathrm{C}=\mathrm{C}), 160.8(\mathrm{C}, \mathrm{C}=\mathrm{O}), 166.0(\mathrm{C}, \mathrm{C}=\mathrm{O})$, $166.2(\mathrm{C}, \mathrm{C}=\mathrm{O}), 172.2(\mathrm{C}, \mathrm{C}=\mathrm{O})$.

IR ( $\mathrm{KBr}$ pellets): $v_{\mathrm{C}=\mathrm{O}} 1718 \mathrm{~cm}^{-1}$.

Anal. Calc. for $\mathrm{C}_{25} \mathrm{H}_{27} \mathrm{BrINO}_{8} \mathrm{PdS}$ : C, 36.85; H, 3.34; N, 1.72 . Found: C, 36.97; H, 3.19; N, 1.56.

\subsection{Synthesis of complex $\mathbf{5 d}$}

Yellow microcrystals. Yield 96\%.

${ }^{1} \mathrm{H}$ NMR (300 MHz, $\left.\mathrm{CDCl}_{3}, T=298 \mathrm{~K}, \mathrm{ppm}\right) \delta: 1.38$ (s, 9H, C $\left.\left(\mathrm{CH}_{3}\right)_{3}\right), 3.21\left(\mathrm{~s}, 3 \mathrm{H}\right.$, quinoline- $\left.\mathrm{CH}_{3}\right), 3.53\left(\mathrm{bs}, 3 \mathrm{H}, \mathrm{OCH}_{3}\right), 3.70(\mathrm{~s}$, $\left.\left.3 \mathrm{H}, \mathrm{OCH}_{3}\right),\right), 3.72\left(\mathrm{~s}, 3 \mathrm{H}, \mathrm{OCH}_{3}\right), 3.91\left(\mathrm{~s}, 3 \mathrm{H}, \mathrm{OCH}_{3}\right), 7.38(\mathrm{~d}, 1 \mathrm{H}$, $\left.J=8.4 \mathrm{~Hz}, \mathrm{H}^{3}\right), 7.61\left(\mathrm{dd}, 1 \mathrm{H}, J=8.2,7.2 \mathrm{~Hz}, \mathrm{H}^{6}\right), 7.93(\mathrm{dd}, 1 \mathrm{H}$, $\left.J=8.2,1.2 \mathrm{~Hz}, \mathrm{H}^{5}\right), 8.01\left(\mathrm{bd}, 1 \mathrm{H}, \mathrm{H}^{7}\right), 8.18\left(\mathrm{~d}, 1 \mathrm{H}, J=8.4 \mathrm{~Hz}, \mathrm{H}^{4}\right)$.

${ }^{13} \mathrm{C}\left\{{ }^{1} \mathrm{H}\right\}$-NMR $\left(\mathrm{CDCl}_{3}, T=298 \mathrm{~K}, \mathrm{ppm}\right) \delta: 29.9\left(\mathrm{CH}_{3}, \mathrm{SC}\left(\mathrm{CH}_{3}\right)_{3}\right)$, 30.1.3 $\left(\mathrm{CH}_{3}\right.$, quinoline- $\left.\mathrm{CH}_{3}\right), 52.0\left(\mathrm{CH}_{3}, \mathrm{OCH}_{3}\right), 52.2\left(\mathrm{CH}_{3}, \mathrm{OCH}_{3}\right)$, $53.1\left(\mathrm{CH}_{3}, \mathrm{OCH}_{3}\right), 53.2\left(\mathrm{CH}_{3}, \mathrm{OCH}_{3}\right), 57.6\left(\mathrm{C}, \mathrm{C}\left(\mathrm{CH}_{3}\right)_{3}\right), 103.5(\mathrm{C}$, $\mathrm{C}=\mathrm{CI}), 124.9\left(\mathrm{CH}, \mathrm{C}^{3}\right), 126.3\left(\mathrm{CH}, \mathrm{C}^{6}\right), 127.5\left(\mathrm{C}, \mathrm{C}^{10}\right), 129.2\left(\mathrm{C}, \mathrm{C}^{8}\right)$, 
$130.9\left(\mathrm{CH}, \mathrm{C}^{5}\right), 133.5(\mathrm{C}, \mathrm{C}=\mathrm{C}), 136.7\left(\mathrm{CH}, \mathrm{C}^{7}\right), 138.5\left(\mathrm{CH}, \mathrm{C}^{4}\right), 146.0$ $(C, C=C), 149.1\left(C, C^{9}\right), 155.5(C, C=C), 160.1(C, C=0), 165.4(C$, $C=0), 166.0(C, C=0), 166.7\left(C H, C^{2}\right), 171.5(C, C=0)$.

IR (KBr pellets): $v_{\mathrm{C}=\mathrm{O}} 1714 \mathrm{~cm}^{-1}$.

Anal. Calc. for $\mathrm{C}_{26} \mathrm{H}_{29} \mathrm{BrINO}_{8} \mathrm{PdS}$ : C, 37.68; H, 3.53; N, 1.69 . Found: C, 37.51; H, 3.42; N, 1.58.

\section{Appendix A. Supplementary data}

CCDC 1449188 and 1449189 contains the supplementary crystallographic data for . These data can be obtained free of charge via http://www.ccdc.cam.ac.uk/conts/retrieving.html, or from the Cambridge Crystallographic Data Centre, 12 Union Road, Cambridge CB2 1EZ, UK; fax: (+44) 1223-336-033; or e-mail: deposit@ccdc.cam.ac.uk. Supplementary data associated with this article can be found, in the online version, at http://dx.doi.org/10. 1016/j.poly.2016.04.008.

\section{References}

[1] (a) M.W. Van Laren, C.J. Elsevier, Angew. Chem., Int. Ed. 38 (1999) 3715;

(b) K. Muñiz, Angew. Chem., Int. Ed. 48 (2009) 2;

(c) L.-M. Xu, B.-J. Li, Z. Yang, Z.-J. Shi, Chem. Soc. Rev. 39 (2010) 712;

(d) J. Vicente, A. Arcas, F. Julià-Hernandez, D. Butista, Angew. Chem., Int. Ed. 50 (2011) 6896;

(e) Y. Dang, S. Qu, J.W. Nelson, H.D. Pham, Z.-X. Wang, X. Wang, J. Am. Chem. Soc. 137 (2015) 2006.

[2] (a) R. Van Belzen, R.A. Klein, H. Kooijman, N. Veldman, A.L. Spek, C.J. Elsevier, Organometallics 17 (1998) 1812;

(b) R. Van Belzen, C.J. Elsevier, A. Dedieu, N. Veldman, A.L. Spek, Organometallics 22 (2003) 722;

(c) A.R. Dick, J.W. Kampf, M.S. Sanford, J. Am. Chem. Soc. 127 (2005) 12790;

(d) L. Canovese, F. Visentin, C. Santo, J. Organomet. Chem. 770 (2014) 6;

(e) L. Canovese, F. Visentin, T. Scattolin, C. Santo, V. Bertolasi, Dalton Trans. 44 (2015) 15049;

(f) L. Canovese, F. Visentin, C. Biz, T. Scattolin, C. Santo, V. Bertolasi, Polyhedron 102 (2015) 94;

(g) L. Canovese, C. Santo, T. Scattolin, F. Visentin, V. Bertolasi, J. Organomet. Chem. 794 (2015) 288;

(h) L. Canovese, C. Santo, T. Scattolin, F. Visentin, V. Bertolasi, J. Organomet. Chem. 808 (2016) 48

[3] (a) R. Zimmer, C.U. Dinesh, E. Nandanan, F.A. Khan, Chem. Rev. 100 (2000) 3067;

(b) J.A. Marshall, Chem. Rev. 100 (2000) 3163;

(c) E.-I. Negishi, in: E.-I. Negishi, A. de Meijere (Eds.), Handbook of Organopalladium Chemistry for Organic Synthesis, Wiley-Interscience, New York, 2002;

(d) K. Tamao, T. Hiyama, E.-I. Niegishi, J. Organomet. Chem. 683 (2002) 1;

(e) A.F. Littke, G.C. Fu, Angew. Chem., Int. Ed. 41 (2002) 4176;

(f) L.A. Agrofoglio, I. Gillaizeau, Y. Saito, Chem. Rev. 103 (2003) 1875;

(g) E. Negishi, L. Anastasia, Chem. Rev. 103 (2003) 1979;

(h) G. Zeni, R.C. Larock, Chem. Rev. 104 (2004) 2285;

(i) K.C. Nicolaou, P.G. Bulger, D. Sarlah, Angew. Chem., Int. Ed. 44 (2005) 4442;

(j) E.-I. Negishi, Bull. Chem. Soc. Jpn. 80 (2007) 233;

(k) C.J. Elsevier, M.R. Eberhard, in: A. Canty, R.H. Crabtree, D. Michael, P. Mingos (Eds.), Comprehensive Organometallic Chemistry III From Fundamentals to Applications, Elsevier, Amsterdam, Boston, 2007, p. 270. Vol. 8, Chapter 8.05;
(1) J.F. Hartwig, Nature 455 (2008) 314;

(m) D.S. Surry, S.L. Buchwald, Angew. Chem., Int. Ed. 47 (2008) 2008 ;

(n) M. García-Melchor, X. Solans-Monfort, G. Ujaque, in: J. Reedijk, K.R. Poeppelmeier (Eds.), CC Bond Formation Comprehensive Inorganic Chemistry II (Second Edition): From Elements to Applications, Elsevier, Amsterdam, 2013, p. 767. vol. 9.

[4] (a) S.L. Buchwald, R.B. Nielsen, J. Am. Chem. Soc. 111 (1989) 2870;

(b) T. Takahashi, M. Kotora, K. Kasai, N. Suzuki, Organometallics 13 (1994) 4183;

(c) T. Takahashi, Z. Xi, A. Yamazaki, Y. Liu, K. Nakajima, J. Am. Chem. Soc. 120 (1998) 1672;

(d) S. Yamaguchi, R.-Z. Jin, K. tamao, F. Sato, J. Org. Chem. 63 (1998) 10060;

(e) Y. Yamamoto, T. Ohno, K. Itoh, Chem. Commun. (1999) 1543-1544;

(f) J. Ryan, G.C. Micalizio, J. Am. Chem. Soc. 128 (2006) 2764.

[5] L. Canovese, F. Visentin, C. Biz, T. Scattolin, C. Santo, V. Bertolasi, J. Organomet. Chem 786 (2015) 21.

[6] L. Canovese, F. Visentin, G. Chessa, P. Uguagliati, C. Levi, A. Dolmella Organometallics 24 (2005) 5537.

[7] L. Canovese, F. Visentin, C. Santo, V. Bertolasi, J. Organomet. Chem. 749 (2014) 379.

[8] K. Moseley, P.M. Maitlis, J. Chem. Soc., Dalton Trans. (1974) 169.

[9] L. Canovese, F. Visentin, G. Chessa, P. Uguagliati, G. Bandoli, Organometallics 19 (2000) 1461.

[10] M.N. Burnett, C.K. Johnson, oRTEP III, Report ORNL-6895, Oak Ridge National Laboratory, Oak Ridge, TN, 1996.

[11] P. Metrangolo, H. Neukirch, T. Pilati, G. Resnati, Acc. Chem. Res. 38 (2005) 386.

[12] A.C. Legon, Phys. Chem. Chem. Phys. 12 (2010) 7736.

[13] G. Desiraju, P.S. Ho, L. Kloo, A.C. Legon, R. Marquardt, P. Metrangolo, P. Politzer G. Resnati, K. Rissanen, Pure Appl. Chem. 85 (2013) 1711.

[14] Z. Otwinowski, W. Minor, in: C.W. Carter, R.M. Sweet (Eds.), Methods in Enzymology, vol. 276 Part A, Academic Press, London, 1997, p. 307.

[15] R.H. Blessing, Acta Crystallogr., Sect. A 51 (1995) 33.

[16] A. Altomare, M.C. Burla, M. Camalli, G.L. Cascarano, C. Giacovazzo, A Guagliardi, A.G. Moliterni, G. Polidori, R. Spagna, J. Appl. Crystallogr. 32 (1999) 115.

[17] G.M. Sheldrick, sHelx-97, Program for Crystal Structure Refinement, University of Gottingen, Germany, 1997.

[18] M. Nardelli, J. Appl. Crystallogr. 28 (1995). 659-659.

[19] L.J. Farrugia, J. Appl. Crystallogr. 32 (1999) 837.

[20] M.J. Frisch, G.W. Trucks, H.B. Schlegel, G.E. Scuseria, M.A. Robb, J.R. Cheeseman, G. Scalmani, V. Barone, B. Mennucci, G.A. Petersson, H. Nakatsuji, M. Caricato, X. Li, H.P. Hratchian, A.F. Izmaylov, J. Bloino, G. Zheng, J.L. Sonnenberg, M. Hada, M. Ehara, K. Toyota, R. Fukuda, J. Hasegawa, M. Ishida, T. Nakajima, Y. Honda, O. Kitao, H. Nakai, T. Vreven, J.A. Montgomery Jr., J.E. Peralta, F. Ogliaro, M. Bearpark, J.J. Heyd, E. Brothers, K.N. Kudin, V.N. Staroverov, R. Kobayashi, J. Normand, K. Raghavachari, A. Rendell, J.C. Burant, S.S. Iyengar, J. Tomasi, M. Cossi, N. Rega, J.M. Millam, M. Klene, J.E. Knox, J.B. Cross, V. Bakken, C. Adamo, J. Jaramillo, R. Gomperts, R.E. Stratmann, O. Yazyev, A.J. Austin, R. Cammi, C. Pomelli, J.W. Ochterski, R.L. Martin, K. Morokuma, V.G. Zakrzewski, G.A. Voth, P. Salvador, J.J. Dannenberg, S. Dapprich, A.D. Daniels, O. Farkas, J.B. Foresman, J.V. Ortiz, J. Cioslowski, D.J. Fox, GAussian 09', Gaussian Inc., Wallingford, CT, 2009.

[21] Y. Zhao, D.G. Truhlar, Acc. Chem. Res. 41 (2008) 157.

[22] Y. Zhao, D.G. Truhlar, Theor. Chem. Acc 120 (2008) 215.

[23] P.J. Hay, W.R. Wadt, J. Chem. Phys. 82 (270-283) (1985) 299.

[24] L.E. Roy, P.J. Hay, R.L. Martin, J. Chem. Theory Comput. 4 (2008) 1029.

[25] C.E. Check, T.O. Faust, J.M. Bailey, B.J. Wright, T.M. Gilbert, L.S. Sunderlin, J. Phys. Chem. A 105 (2001) 8111.

[26] V. Barone, M. Cossi, J. Tomasi, J. Chem. Phys. 107 (1997) 3210.

[27] V. Barone, M. Cossi, J. Phys. Chem. A 102 (1998) 1995.

[28] (a) C.J. Cramer, Essentials of Computational Chemistry, second ed., Wiley, Chichester, 2004;

(b) F. Jensen, Introduction to Computational Chemistry, second ed., Wiley, Chichester, 2007. 